\title{
Analysis of Debt Leveraging in Private Power Projects
}

Edward P. Kahn

Meg Meal*, Siegfried Doerrer and Susan Morse

Energy \& Environment Division

Lawrence Berkeley Laboratory

University of California

Berkeley, CA 94720

- Morse, Richard, Weisenmiller \& Associates, Inc.

1999 Harrison Street, Suite 1440

Oakland, CA 94612

August 1992

The work described in this report was funded by the Deputy Undersecretary for Policy Planning and Analysis, Office of Electricity, Coal, Nuclear and Renewables Policy, of the U.S. Department of Energy under Contract No. DE-AC0376 SF00098. 


\section{Contents}

\section{Page}

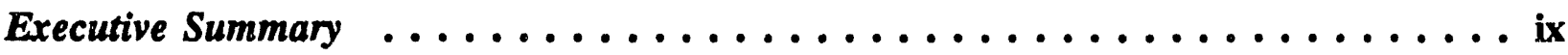

Chapter 1 Scope of this Study ......................... 1

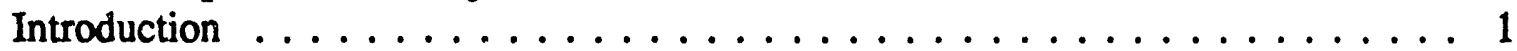

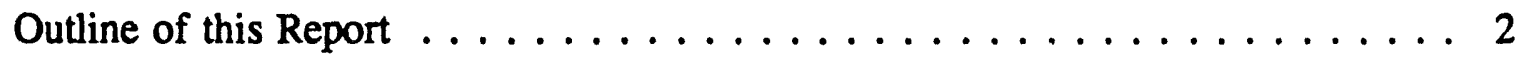

Chapter 2 What Does the Lender Do? . . . . . . . . . . . . . . . . . . 3

Project Finance vs. Corporate Finance . . . . . . . . . . . . . . . . 3

The Project Lender's Role in Risk Allocation and Management . . . . . . . . . . . 4

Chapter 3 The Sample of Private Power Loans: Data and Limitations . . . . . . . 13

Description of Contract Sample . . . . . . . . . . . . . . 13

Limitations of Publicly Available Documentation . . . . . . . . . . . 17

Chapter 4 A Typology of Loan Covenants . . . . . . . . . . . . . . . . . . 19

Introduction . . . . . . . . . . . . . . . . . . . . 19

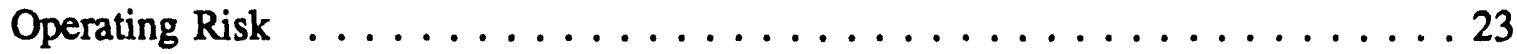

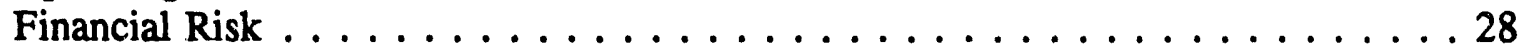

Fuel Risk . . . . . . . . . . . . . . . . . . . . . 33

Regulatory and Environmental Risk . . . . . . . . . . . . . 35

Default Provisions . . . . . . . . . . . . . . . . . 36

Chapter 5 Implications of Debt Leveraging in Electric Power Supply _ . . . . 37

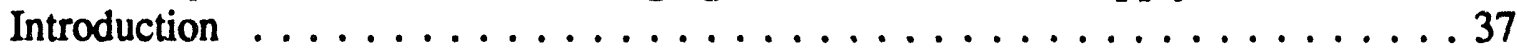

Reliability Effects of Leverage . . . . . . . . . . . . . . . . . . 37

The Impact of Purchased Power on the Utility Cost of Capital . . . . . . . . . . 43

Capital Structure and Competitive Advantage . . . . . . . . . . . . . . . 49

Future Directions . . . . . . . . . . . . . . . . . . . . . 54

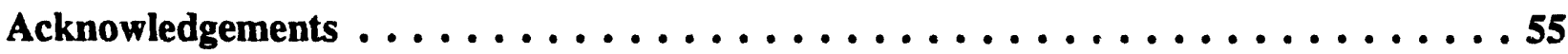

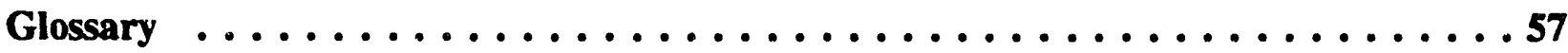

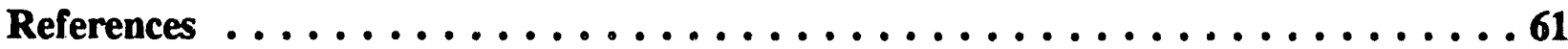




\section{List of Tables}

Table

Title

Page

Table 2-1 Developer's and Lender's Roles in Project

Development and Operation ..................... 6

Table 2-2 Typical "Conditions Precedent" in Loan Agreements . . . . . . . . . . . . . 10

Table 3-1 Contract Sample . . . . . . . . . . . . . . . . . . . . . . . . 14

Table 5-1 MCV Operating Margin Sensitivity . . . . . . . . . . . . . . . . . . 40

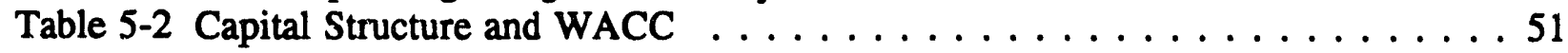

Table $5-3$ Capital Recovery Factor . . . . . . . . . . . . . . . . . 53 


\section{List of Figures}

\begin{tabular}{lll}
\hline Figure & Title & Page \\
\hline
\end{tabular}

Figure 4-1 Typical "Waterfall" Structure $\ldots \ldots \ldots \ldots \ldots \ldots \ldots \ldots \ldots \ldots$ 


\section{Executive Summary}

As private power has grown to become a significant part of the electricity system, increasing concern about its financial implications has arisen. In many cases, the source of this concern has been the substantial reliance of these projects on debt financing. This study examines debt leveraging in private power projects. The policy debate on these issues has typically been conducted at a high level of generality. Critics of the private power industry assert that high debt leveraging confers an unfair competitive advantage by lowering the cost of capital. This leveraging is only possible because risks are shifted to the utility. Further, debt leveraging is claimed to be a threat to reliability. On the opposite side, it is argued that debt leveraging imposes costs and obligations not borne by utilities, and so there is no financial advantage. The private producers also argue that on balance more risk is shifted away from utilities than to them, and that incentives for reliability are strong.

In this study we examine the project finance mechanisms used in private power lending in detail, relying on a sample of actual loan documents. This review and its findings should be relevant to the further evolution of this debate. State regulatory commissions are likely to be interested in it, and Federal legislation to amend the Public Utility Holding Company Act (PUHCA) could require states to consider the implications of debt leveraging in relation to their oversight of utility power purchase programs.

\section{Project Finance Lending}

We review evidence on the allocation and management of risks in a sample of actual lending agreements between financial institutions and private power producers. Each of the private power projects in the sample was financed on a non-recourse basis where the senior lender looks solely to the assets and cash flows of the project for repayment. In total, a modest sample of twelve projects of varying sizes with different kinds of lenders and owners was collected. Projects in the sample vary across fuel type, technology, and purchasing utility, but are not intended to be a representative cross-section of the industry. Rather, the sample was reviewed to identify prototypical risk allocation and management mechanisms, and to identify more restrictive terms and conditions on a case-by-case basis.

The lender's role in risk allocation and management is to review the quality of the project, its contracts and participants to determine the level of risk and appropriate pricing associated with the loan. The lender's credit review process provides an independent assessment of risk allocation and project quality. In the loan agreement itself, the lender will impose constraints on the behavior of project owners and operators to preserve this risk allocation and to manage risks over the long term. This process can serve to improve project viability and reliability. The process is much more constraining than corresponding features of corporate finance, where lenders can look to a portfolio of assets as support for their loans. 
Our review of project finance for private power shows a consistent approach to imposing operational and financial constraints on project developers and owners. Some loan agreements have more restrictive provisions than others. The reasons for these variations would require more extensive analysis. Further, the review of sample loan agreements ignores variations in the quality of different lenders' credit standards or variations in lenders' enforcement of loan terms. Finally, corporate loans or loans with recourse to project sponsors typically impose fewer constraints. We list below the major areas in which lenders allocate and manage risk.

\section{Construction Risk}

Virtually all of the agreements impose constraints to assure that the project will be built on time, on budget, and will meet performance expectations. Mechanisms include independent engineering review of design, budget and schedule prior to the start of construction, and a limitation on fundings of the construction loan according to achievement of agreed-upon milestones.

\section{Operating Risk}

All of the agreements include mechanisms to impose operational controls on developers designed to assure that the project will operate as efficiently and reliably as expected. These mechanisms include restrictions on changes to the primary project contracts (power purchase agreement, fuel supply and transport, construction and operating and maintenance contracts), reporting requirements, lender oversight of operating budgets and expenditures, requirements to establish and fund reserves for periodic overhauls, and restrictions on the developer's ability to engage in other businesses.

\section{Financial Risk}

Financial constraints imposed in most or all of the agreements include prohibitions on additional debt or liens, restrictions on sale of project assets, maintenance of debt and working capital reserves, and restrictions on the developer's access to project cash flows until all outstanding obligations are satisfied.

\section{Fuel Risk}

The lender's credit review process will generally involve an extensive review of fuel supply and transport arrangements that are put in place prior to the execution of the loan agreement. The loan agreement itself will attempt to preserve and maintain these arrangements over the term of the loan. All of the loan agreements prohibit material changes to fuel supply and transport agreements, and some provide for reporting on the financial condition of suppliers and 
transporters, or a default if the suppliers or transporters should fail to meet their obligations to the project.

\section{Regulatory and Environmental Risk}

All of the loan agreements require assurances that all permits and other necessary governmental approvals are in place or will be obtained, and that the project will be able to operate within limitations imposed by permits. All of the loan agreements require the developer to stay in compliance with regulations and obtain new permits or approvals as necessary. All of the loan agreements provide that the project be a qualifying facility or have other necessary FERC approvals, and that these approvals be maintained.

Most of the agreements specify that a default has occurred if a change in regulations has an adverse effect on the viability of the project.

\section{Implications of Leveraging for Utility Purchasers}

The detailed structure of project finance loan agreements was investigated to see what light the actual practice of this type of lending might shed on certain questions about debt leveraging which have arisen in the legislative debate concerning amendment of PUHCA.

\section{Reliability Effects of Leverage}

Some participants in the debate asserted that because private producers do not have the obligation to serve, they will not provide reliable supply. The connection between a high degree of leverage and reliability problems rests primarily on the fact that project revenues may be only slightly greater than debt service requirements and operating costs. With such narrow margins, projects might fail under adverse circumstances.

The project finance loan agreements provide extensive protection against such eventualities through maintenance and overhaul reserves, insurance, debt reserves and independent engineering oversight. In fact, there is even some reason to believe that high leverage induces closer management attention to reliability and therefore superior performance to the behavior of regulated utilities. The record is still too limited to prove such a case. But our survey of project finance does show that a strong system of controls is typically established in the financial structure of private power projects which assures a high probability of performance. The high threshold requirements for availability typically contained in power purchase agieements encourage this attention because capacity payments are at risk.

The project finance structure is not impervious to reliability problems. There can be ambiguities or complexities in the contractual relationships among the construction contractors, equipment 
vendors and O\&M contractors. These may present particular problems for newer and riskier technologies. The conservative nature of the financial community has not constrained private power developers to avoid new technology, and the benefits of its success will accrue to developers, constructors and operators who have been willing to accept and manage that risk.

Of the various questions raised to date about debt leveraging, the reliability issues are probably the most straight-forward. As long as lenders must be repaid, there will be strong incentives to perform reliably.

\section{The Impact of Purchased Power on the Utility Cost of Capital}

There are two aspects of this issue. One is the notion of "debt equivalence," which focuses on the degree to which long term purchase arrangements impose unconditional liabilities on utilities, or raise risks that costs may not be recovered. The other aspect is comparative; what would the utility have done in the absence of long term purchase contracts, and what would be the financial implications of such alternatives.

This is probably the most indeterminate of all the leveraging issues, and our investigation of project finance has little to say about it. Most of the "debt equivalent" features of long term purchase arrangements involve aspects of the power purchase contract. The commitment to purchase power and make capacity payments imposes an obligation on the utility. Some contract clauses mitigate this obligation, particularly performance standards. The degree to which cost recovery procedures determined by state regulatory commissions are not automatic can also limit the liability. While there is something to the notion of debt-equivalence, it is difficult to measure. If the utility did not purchase power under long term contracts, it would typically also have to increase its financial liabilities, with negative impacts on the cost of capital. The relative importance of these effects in the "build versus buy" decision is difficult to measure. In the long run, if the private power producers' market share continues to increase significantly, then cost of capital questions may merge increasingly with larger strategic questions about the role of vertical integration. If utility ratebases decline substantially because long term purchases displace utility investment in generation assets, then the problem of diminishing equity will become increasingly important. Assessing policy choices and strategies regarding long-run competition for market share is a research issue.

Cost of capital issues in utility regulation have always had a major judgmental element. With the growth of the private power industry and the questions raised by the debt-equivalence argument, the role of judgment is not likely to diminish. 


\section{Capital Structure and Competitive Advantage}

The cost of capital discussion identified an underlying struggle for market share between private producers and franchised utilities. This struggle forms the background for much of the policy debate surrounding debt leveraging. We address the question explicitly by asking if project financing in some way tilts the competitive struggle unfairly. Some defenders of franchised utilities argue that the high leverage of project finance is an "unfair" competitive advantage.

We concentrate on two elements of project finance that have been somewhat obscured in the previous policy discussion. First, the role of sub-orainated debt in project finance shows that there are important subtleties associated with the classification of financing instruments as either debt or equity. Second, the financial effect of shorter loan maturities turns out to be the dominant effect with regard to competitive advantage in financing. It favors the utility corporate finance structure.

The project finance structure is sufficiently different from utility corporate finance that simple comparisons can be misleading. For example, hybrid financing instruments like subordinated debt are difficult to classify as debt or equity. Their costs and priority of payment are closer to equity; the fixed interest rate, mandatory principal repayment, and tax deductibility are closer to debt. For comparison to the cost and capital structure of utility corporate finance, the cost factor is more important, and therefore we classify subordinated debt as an equity substitute for capital structure purposes.

The weighted average cost of capital (WACC) is one measure of financing cost. WACC is typically somewhat lower for project finance than for corporate finance because of greater leverage. Project finance, however, usually involves both higher debt costs and higher costs of equity than utility corporate finance. Differences in WACC are offset by the financial burden of the short loan maturities typical in project finance. When this factor is taken into account, there is no generic competitive advantage for either private producers or franchised utilities.

Finally, any assessment of competitive financing advantage must examine not only the structure of project finance, but also a reasonable estimate of the utility's marginal capital structure. On the margin, the utility's capital structure can be quite different from its average capital structure.

\section{Summary}

Ultimately, state regulatory commissions will have to grapple with these issues. Increased knowledge of project finance techniques should ease concern about reliability issues. Cost of capital issues will be a long term question pertaining to the market share struggle. In the current market, project finance imposes a competitive disadvantage on private power due to short loan maturities. As the financial market evolves this may change. 


\section{Chapter 1 \\ Scope of this Study}

\subsection{Introduction}

This paper examines the public policy implications of the methods used by private power producers to finance their projects. These methods typically differ from the procedures commonly used by regulated investor-owned utilities (IOUs) to raise capital. IOUs depend primarily on corporate finance, whereas the private power industry has been historically financed by project finance structures. The debate over the implications of these practices has frequently ignored qualitatively important differences between the two types of financial structure. As a result, some of the comparisons made are at best incomplete and uninformative.

In this paper we address the financial structure of private power projects directly by examining directly the process of lending to this industry. We survey the senior loan agreements underlying a small, but significant sample of these projects. This survey provides a characterization of the lending process, and the control structure associated with it, that is substantially more complete than what has previously been used by disputants in the public debate. Throughout the discussion we will draw parallels or contrasts with procedures typical in a corporate finance framework. Having completed this survey, we will then return to issues raised by the difference in financial structure and see what light can be shed upon them by the empirical research.

As a framework for the policy discussion, we focus in particular on three issues associated with the capital structure of private power projects that have appeared in the debate concerning Federal legislation to amend the Public Utility Holding Company Act (PUHCA). The proposed legislation developed by the Senate (S.2166) would require state regulatory agencies to consider three questions (Section 15107). These are:

(1) whether there are increases or decreases in the cost of capital for regulated electric utilities as a result of long-term wholesale purchases;

(2) whether long-term purchases from suppliers with capital structures having greater portions of debt than regulated utilities will have adverse implications for the reliability of eleatric service, and

(3) whether private suppliers using capital structures with less than $35 \%$ equity have an unfair competitive advantage over regulated utilities.

These questions are formulated at a very general level. The purpose of this discussion is to explain in some detail how the risks of power plant development are allocated and managed by the private power industry. While this analysis does not attempt to provide answers to the 
questions raised in Section 15107 of S2166, it can provide the basis for a more focused discussion of the underlying issues.

\subsection{Outline of this Report}

We begin in Chapter 2 with a background description of the lending process, contrasting corporate finance with project finance. Once these initial distinctions are clarified, we give an overview characterization of the project lending process as it applies to the private power industry. Chapte: 3 characterizes the empirical basis of the discussion by describing the sample of loan agreements reviewed and the data problems associated with studying what are essentially private and confidential business documents. In Chapter 4 we give a systematic account of how the important risk elements of a private power project are typically allocated and managed through the structuring of loan agreements. This chapter reviews (1) construction risk, (2) operating risk, (3) financial risk, (4) fuel risk, (5) regulatory and environmental risk, and (6) default provisions. Chapter 5 returns to the questions raised explicitly in Section 15107 of S2166. For each of these questions, we briefly review thie debate and assess what light the prior discussion sheds on these issues. 


\section{Chapter 2 \\ What Does the Lender Do?}

\subsection{Project Finance vs. Corporate Finance}

Not all debt is alike. Some may be sold to the public through bond offerings; some may be placed privately with a limited number of financial institutions. The bank term loan, for example, is an important kind of private debt. For our purposes, there is an equally important distinction, the difference between corporate borrowers and single-asset project financing. When corporations borrow money in either the public or private markets, the support for their credit is generally income streams coming from many assets. The vast majority of corporations sell more than one product, so the total income stream is diversified over the sales of each product. By contrast, project finance is built around the notion that income from a single asset is sufficiently secure that further asset diversification is not necessary to support borrowing.

In the electric utility industry, IOUs sell bonds or borrow from banks based on the revenues generated by assets in the transmission and distribution functions of their business as well as from the wholesale generation segment. Private power producers, by contrast, generally finance projects on a stand-alone basis. The credit support for project finance comes in large part from the power purchase agreement between the project developer and the purchasing utility. This agreement reduces the risk that the project will not find a buyer for its product. This risk reduction has been discussed at some length by critics of the private power industry (Raboy 1991; Luftig and Perl 1990). The implications of this risk reduction are discussed in Section 5.1 below. While it is clearly the enabling condition for a project finance structure, there remain substantial risks in these projects which must be allocated and managed.

The lender's problem in the case of project finance is to assure that revenues from the single asset will be sufficient to repay the loan. Ultimately, repayment depends upon the economic viability of the project. The power purchase agreement assures that there will be a buyer for the project output at specified prices and performance levels. The lender must be assured that costs will be sufficiently below revenues to generate enough cash to meet debt service payments with an acceptable margin. It is equally important to assure that performance requirements, which are always part of the power purchase agreement (Kahn 1991), can be met by the project developer. To provide this assurance, lenders include extensive restrictions, called loan covenants, in their agreement with borrowers. In the next section of this Chapter, we describe the process of negotiation which leads to these covenants. Chapter 4 describes them in detail for the sample of projects characterized in Chapter 3. Broadly speaking, the loan covenants restrict the borrower's freedom of action in ways that help assure the lender that not only will things work as expected, but that prudent measures have been taken to deal with possible adversities.

Typically, public corporate lending lacks the degree of specificity found in project finance. Lenders in such cases do not always receive liens and seldom spell out in as much detail what 
the borrower may and may not do. For publicly sold bonds, the main type of covenant is a restriction on the issuing of debt beyond certain limits (Smith and Warner 1979). Additional debt can hurt bondholders because it reduces the ability of the firm to pay interest on existing debt. Another common bond covenant is a restriction on the amount of dividends that a company may pay. Apart from these financial restrictions, publicly sold bonds have few covenants that address the management of the firm's assets. Privately placed bonds and bank loans, on the other hand, will commonly have many more of the kinds of restrictive covenants that we see in project financing. One reason for the difference is that public bonds are actively traded in secondary markets. As such they must be more or less standardized commodities. The kind of specificity that can be negotiated between private parties does not easily translate into a tradable security that anonymous buyers and sellers easily understand and can value.

There are, of course, numerous subtleties characterizing the bond and debt markets generally (Fabozzi and Pollack 1987). For our purposes, the distinction between corporate bond financing and froject financing is essential. The principal form of utility debt is publicly traded bonds, where covenants play a limited role. Lenders get assurance from the asset diversity of firms, their franchised monopoly, and the implicit social contract with regulatory agencies to maintain the existence of firms barring major catastrophic events. These facts are uncontroversial and widely acknowledged. To the degree that firm specific circumstances influence the riskiness of utility bonds, investors rely upon the judgments of credit rating agencies to assess relative risk. These assessments are the bond ratings given to the securities of firms that determine their relative price and the interest rates utilities pay when they sell new bonds,

The capital formation process in the private power industry is less well known generally, although it is becoming increasingly standardized. In the discussion which follows, we outline the participation of lenders in the private power development process. This is a much more active process than what the typical purchaser of a utility bond undertakes (Kensinger and Martin 1988). Our general characterization of the project lending process will serve as background for the more specific analysis of project risk management which follows. Our discussion draws upon useful perspectives on the contractual structure of the private power industry have been developed by the law firms experienced in these transactions (Fletcher et al. 1991) and the credit rating agencies (Standard and Poor's 1991), which are just beginning a systematic assessment of this industry.

\subsection{The Project Lender's Role in Risk Allocation and Management}

Private power projects are essentially a structure of contracts designed by developers to bring the factors of production together for a specific configuration. It is the developer's role to structure the project's contracts so that the inherent risks of power generation are allocated to those project participants who are willing or able to bear them. The developer's reward for allocating risks carefully is the opportunity to secure construction and permanent financing at an attractive rate, thereby profiting on the difference between costs of production and power purchase prices. 
The lender's role is to review the structure of the project and the quality of the project participants to assess the level of risk associated with a potential loan to the project, and to price the loan appropriately for the level of risk assumed. The lender will seek to limit its risk exposure at the outset, and to impose constraints on the behavior of project owners and operators to manage risks over the life of the investment.

The lender's commitment is made toward the end of the project development process, in contrast to the utility's commitment to purchase power, which is made in the initial stages of project

development. As a result, the lender has both the ability and the incentivc to exert its influence over the final structure of all project contracts (including, as the result of negotiations, the power purchase agreement), and to structure the loan agreement to control and restrict the developer's activities under those contracts. In theory, then, the lender can impose controls and restrictions on project owners beyond what is typically found in power purchase agreements, improving project viability and reliability, to the benefit of the utility and its ratepayers. Through a review of a sample of loan agreements, this paper assesses how and the extent to which these viltrols and restrictions are in fact imposed on project owners.

\subsubsection{Process of Making a Loan}

Table 2-1 shows the steps in the project development process and the role of the project lender in that process. In contrast to the power purchase agreement, which is typically negotiated and executed very early on in the project development process, the loan agreement is generally the last major agreement that the developer must secure to start project construction.

Typically, the following project contracts will be executed prior to or simultaneously with execution of construction financing documents:

- power purchase agreement

- construction contract

- fuel supply and transport agreements

- operating and maintenance agreements

- waste disposal agreements

- ancillary financing agreements (equity funding commitments, interest rate protection, etc.)

Aithough many contracts may be executed prior to active involvement of the lender, the developer knows that all project contracts will have to be negotiated and structured to the lender's satisfaction, giving the lender significant influence over the final characteristics of the project. In making a loan decision, the lender examines the extent to which project risks are shifted to participants who are equipped to manage and control them, so that operating margins are maintained over the long run and investment value is preserved. Often, contracts (including power sales agreements) are renegotiated or amended to meet lender requirements. The 


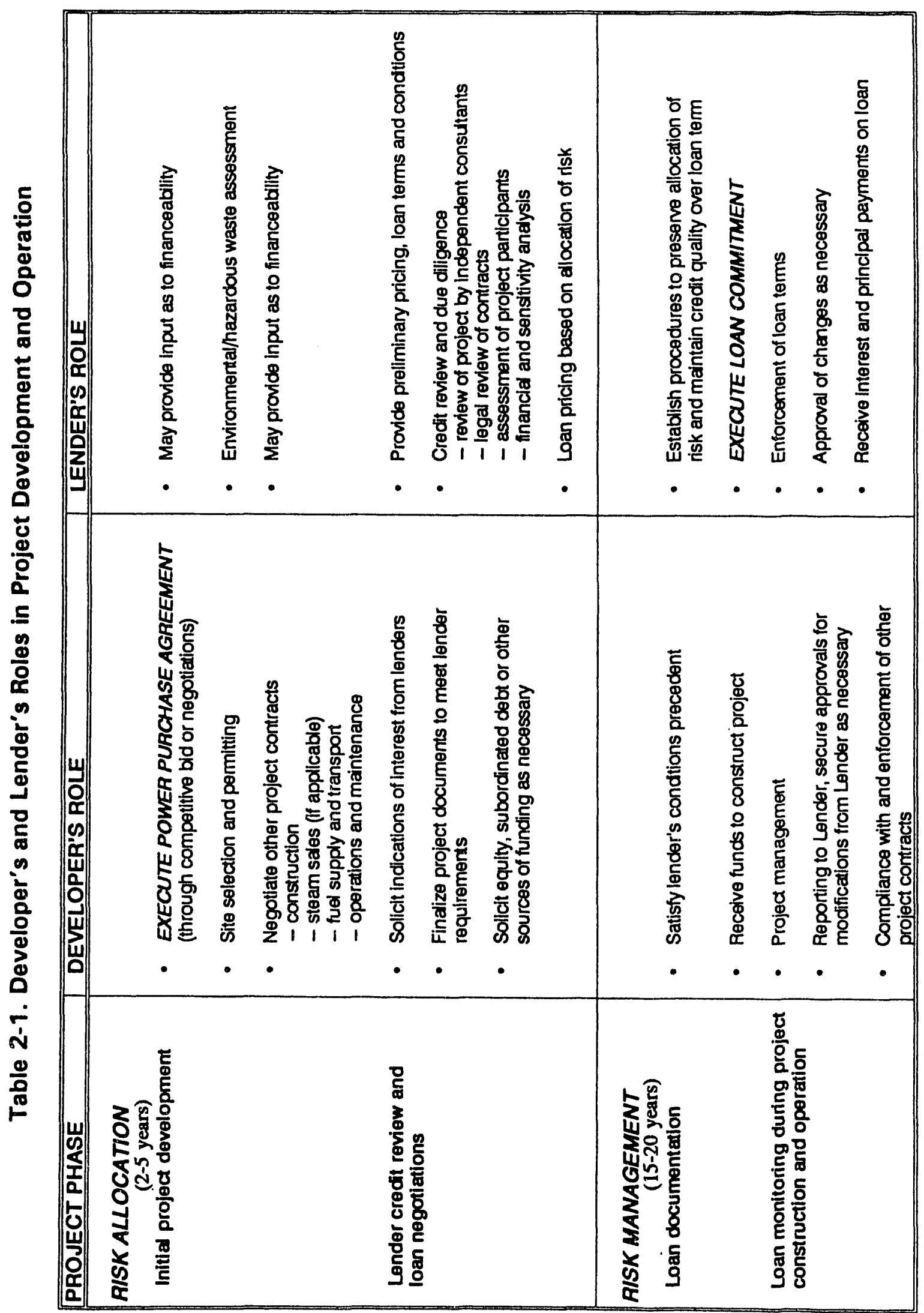


developer's incentive to structure contracts to meet lender's requirements is, ultimately, a lower cost of financing.

The lender's involvement in the project exists in three stages: (i) credit review, (ii) loan documentation, and (iii) loan monitoring. Risk allocation occurs during the credit review process and risk management occurs during loan documentation and loan monitoring, as described below.

(1) The credit review process (or "due diligence" process) starts during the project development stage, typically after a power purchase agreement has been executed. In some cases, lenders will provide preliminary feedback to developers as to the "financeability" of certain contract provisions prior to contract execution, or will provide preliminary indications of interest in financing to be included as part of a developer's bid package for a utility RFP. The lender will assess the quality of the relevant project contracts and the quality of the contracting parties, among other things. Although the level and extent of credit review will vary from lender to lender, this process provides an independent assessment of project viability, project risks, how those risks have been allocated, and to what extent the contracting parties are able to bear those risks.

During the credit review process, the lender typically engages independent consultants to assess specific kinds of project risks and proposed mitigation strategies. These reviews could include the following:

- independent engineering review of project design and equipment specifications, review of the reasonableness of the construction budget, schedule and performance testing requirements, and verification of operating assumptions used in pro forma projections of revenues and expenses;

- independent review of fuel supply and transport arrangements, the adequacy of supplier's reserves, availability of alternatives, potential for interruption of firm transportation, and review of projections of the cost of fuel and price of electricity (utility's avoided cost) under different dispatch scenarios and fuel escalation rates;

- independent review of insurance policies to verify that required insurance is in place and that carriers meet quality requirements;

- independent review of the site by an environmental consultant for hazardous wastes, and review of the adequacy and quality of permits or other approvals required for construction and operation of the project. 
Input from these independent consultants often results in modifications to the project to better allocate risks, including modification of contract pricing provisions, changes in the design and engineering of the project (such as provision of redundant equipment), and modifications to the construction budget and schedule.

For a more complete discussion of what a lender looks for in specific project contracts, see Fletcher et al., 1991.

(2) The loan documentation process is intended to provide the lender with assurances that the structure of the contracts, the quality of the contracting parties, and the performance and profitability of the project will be maintained over the term of the loan. The loan documeni establishes procedures to be followed throughout the course of the loan, and outlines steps to be taken when problems arise.

(3) The loan monitoring process commences once the loan documentation process is completed, and continues through the construction and operating phases of the project. In this phase, the lender enforces the terms and conditions of the financing agreements.

At this point, it should be noted that our emphasis is on the requirements and restrictions placed on project owners through the loan documentation, rather than on the lender's credit review and due diligence performed in advance of making an investment decision. Credit review, due diligence and loan negotiations occur "behind closed doors" and are not well-documented, except to the extent of conditions precedent included in the loan documentation (see Section 2.2.2). As such, it would be extremely difficult to assess variations in standards for credit review across lenders or projects. Further, we have made no attempt to assess variations in how lenders may enforce particular loan provisions. Instead, our review of loan documentation assesses the extent to which lenders improve the "quality" of a project by requiring that certain enhancements be in place prior to making the loan commitment, by providing owners with incentives to maintain project quality and by outlining steps to be taken when problems arise.

Implicit in our approach in this report is the assumption that lenders are doing their job properly in terms of credit review and risk assessment. The validity of this assumption is supported by the fact that some projects with power purchase agreements are never constructed, and in other cases power purchase agreements are renegotiated or restructured prior to the start of construction. The reasons for project failure or contract restructuring are many (including inability to secure adequate fuel supplies, permitting and siting difficulties, and the like), but often result from lenders' discomfort with allocations of risk and unwillingness to accept certain project risks, as evidenced by their refusal to provide sufficient financing for a project at a reasonable cost.

Finally, the costs of credit review, loan documentation and loan monitoring, including the fees paid to independent consultants, are capitalized into the project loan itself. This is analogous to 
the more familiar process in residential mortgage lending where "due diligence" cost (i.e. appraisals and credit checks) and loan processing costs are capitalized into the mortgage loan.

\subsubsection{Elements of Loan Documentation}

While loan agreements vary, the relevant provisions can be categorized as follows:

(1) Conditions Precedent. Conditions precedent are conditions that must be met before the lender is required to meet its obligations to advance funds to the project. Conditions precedent provide a checklist of steps that the developer must take to satisfy the lender that the project is and will continue to be viable. Conditions precedent are generally of three types: (i) conditions precedent to the first funding under the construction loan, (ii) conditions precedent to each subsequent funding under the construction loan, and (iii) conditions precedent to conversion from the construction loan to the term loan (permanent financing). A list of typical conditions precedent is shown in Table 2-2. Generally, conditions precedent provide assurances that all that needs to be in place for the project to be constructed and operated as originally expected is in fact in place prior to advancing funds to the project. In the following sections, this report describes the conditions precedent found in the sample of loan agreements according to the risk (construction, operating, financial, fuel and regulatory) to which each condition relates.

(2) Representations and Warranties. Representations and warranties are statements regarding the project and the developer that the developer certifies to the lender as true at the time they are made. These include, for example, certifications that the developer has the legal authority to execute the contracts, all required permits are in place, all contracts that are needed for project construction and operations are executed, budgets and projections were prepared with due care and good faith, etc. These certifications provide the lender with assurances that the information the developer has provided during the credit review process is correct.

(3) Affirmative and Negative Covenants. Covenants are actions the borrower agrees to take (affirmative) or not take (negative) during the term of the loan agreement. Covenants, as described in detail in the subsequent sections, are the primary mechanism the lender has to control the future activities of the borrower, and therefore preserve or maintain the viability of the project. 
Table 2-2. Typical "Conditions Precedent" in Loan Agreements

Conditions precedent to construction loan:

- All project contracts executed and delivered

- Legal opinions as to contract enforceability and legality

- Construction budget and schedule delivered (funding sources sufficient to complete project, s'hedule within deadlines in power purchase agreement)

- Operating projections delivered (project cash flows sufficient to service debt with adequate coverage)

- Independent consultant reports (independent assessment of project viability)

- Engineering review

- Fuel supply and transport review

- Environmental/site review

- Insurance review

- Required permits in place

- Required insurance in place

- Initial reserves funded

- Equity commitments in place

- Security documents in place (providing for a pledge of all project assets, including equipment, permits, contracts and project revenues, to lender)

Conditions precedent to fundings under construction loan:

- Approval of drawdowns by lender/lender's engineer

- Construction proceeding on time and on budget

- Permits aquired as needed

- No changes to project contracts or projections

Conditions precedent to conversion to term loan:

- Project completed within budget

- Project passes performance tests (output, fuel consumption, emissions)

- Working capital, debt service and other reserves adequately funded

- Required permits to operate in place 
In a discussion of the importance of covenants in determining debt ratings, Standard \& Poor's provides a good description of the role of covenants in the ability of the lender to manage project risks over the life of the loan:

Covenants provide a framework for lenders to reach an understanding with a borrower regarding how the borrower will conduct its business and financial affairs. Through covenants, lenders, in effect, become partners with the borrower (Standard \& Poor's 1992).

Both borrower and lender will be happiest if the lender's role is that of a "silent partner, ${ }^{n}$ indicating that the project is operating as expected. If the project gets into trouble, however, the lender will want to be actively involved in working out solutions:

Covenants can limit management actions that would damage the lender's position. If covenant tests are well conceived, the lender will receive early warning signals of credit deterioration. Such early warnings can bring lender and borrower to the negotiating table to take appropriate actions before the credit has deteriorated beyond the lender's risk tolerance level. The stronger the covenant package is, the greater control the lender can exercise over the investment. (Standard \& Poor's 1992)

(4) Defaults. The lender has no ability to control the borrower unless the lender can take some specific action if the borrower violates a provision of the loan agreement. Defaults are events which allow the lender to take certain actions (remedies), giving the borrower an incentive to prevent a default from occurring. A default can occur if (i) the borrower violates a provision of the loan agreement (sometimes subject to various grace periods), (ii) the borrower violates a provision of another project agreement (cross default) or (iii) some event occurs that may or may not be out of the control of the borrower but threatens the project in some way (for example, bankruptcy or violation of a project document by another project participant, or adverse changes in law).

(5) Remedies. Remedies are actions the lender can take against the borrower if a default occurs, and provide the borrower with the incentive to co'nply with loan terms and conditions. First, an event of default will result in an immediate increase in the interest rate on the loan. In the most extreme case, the lender will take over or sell all of the borrower's assets (the project). Other steps can include acc. "r.ration (the balance of the loan is immediately due), replacement of the managiilg partner, replacement of other contracting parties, or blockage of payment of distributions or dividends to project owners. ${ }^{1}$ In general, however,

\footnotetext{
${ }^{1}$ Variations in remedies across the sample have not been reviewed in detail. Often, specifics on remedies are included in separate security documents which were not generally available for projects in the sample. In general, it can be said that the remedies across all projects appear to give the borrower sufficient incentive to comply with the loan terms and conditions.
} 
the lender wants these remedies so it has the opportunity to "be at the table" when problems arise and alternative solutions are being discussed.

(6) Security Agreements. In addition to covenants to regulate the enterprise's business practices, lenders require that all assets and contracts be pledged as security for the loan. If the borrower is unable to meet its obligations under the loan agreement, the lender may, after certain steps, take over the project's assets, be recognized by all project participants as the new project "owner, " complete construction of the project, and operate the project or sell all the assets.

Lenders typically receive a security interest in the project's real estate, leases, improvements, personal property, insurance proceeds, cash receipts, bank accounts, etc, and sometimes a lien on the developer's partnership interest. In addition, lenders are granted assignments or pledges of all major project documents. Through these assignments, utilities, steam hosts, construction companies, fuel suppliers and other project participants are required in the event of a default by the borrower to continue performance under their contracts, to recognize the lender instead of the borrower as the party with which it deals, and to accept payments from the lender for obligations due by the borrower. These pledges and assignments give the lenders the ability to step into the shoes of the borrower and operate the facility, thereby further protecting their investment. 
Chapter 3

\section{The Sample of Private Power Loans: Data and Limitations}

\subsection{Description of Contract Sample}

Table 3-1 summarizes the sample of loan agreements that were analyzed in this study. Eight of the loan agreements were made available for review on the condition that the projects only be described generically; the loan agreements are proprietary information. Public information was available for four projects, three that were financed, in part, through tax-exempt bonds issued by local financing authorities, and one, the Midland Cogeneration Venture, that sold bonds to the public after the project was completed.

For each project, project size, fuel type, location, date financed, type of lender, type of owner, and type of document available for review are listed. While the sample is not intended to be a representative cross-section of the industry, the sample does cover a broad range of project sizes, types, and locations. Most of the projects in the sample were financed in 1990 or 1991 . The oldest project in the sample was financed in 1987. Perhaps most important for a review of loan agreements, nine different lenders and twelve different developer/owners are represented. The lenders range across foreign and domestic commercial banks, insurance companies, and the public. The owners are utility subsidiaries, project development companies, or affiliates of equipment vendors or other project contractors (e.g., construction). Projects in the sample with owner/participant affiliations are shown below. Note that some projects have multiple affiliations.

Project participant

Constructor

Operator

Fuel Supplier

Equipment Vendor

Projects with no known ownership by project

participants
Projects in Sample with Some Known Ownership by affiliate of participant
5

7

2

2

4

Although the power purchase agreements for each project were not reviewed in detail, the terms of those agreements vary across the sample. Only two projects have contracts with the same utility. Some projects are dispatchable and some are not. 
Table 3-1. Contract Sample

\begin{tabular}{|c|c|c|c|c|c|c|c|}
\hline Prolect Name & $\begin{array}{l}\text { Size } \\
\text { MW }\end{array}$ & Fuel & State & $\begin{array}{c}\text { Date } \\
\text { Closed }\end{array}$ & $\begin{array}{l}\text { Lender } \\
\text { Type }\end{array}$ & $\begin{array}{l}\text { Owner } \\
\text { Type }\end{array}$ & Documents Reviewed \\
\hline \multicolumn{8}{|c|}{ Proprietary Documentation Reviewed: } \\
\hline A & 50 & CMC & wV & 1989 & $\mathrm{CB}$ & US,D,V & $\begin{array}{l}\text { Construction and Term } \\
\text { Loan Agreement }\end{array}$ \\
\hline B & 120 & NG & CA & 1987 & 1 & US,D & $\begin{array}{l}\text { Construction and Term } \\
\text { Loan Agreement }\end{array}$ \\
\hline C & 30 & WW & CA & 1989 & $\mathrm{CB}$ & D & $\begin{array}{l}\text { Construction and Term } \\
\text { Loan Agreement }\end{array}$ \\
\hline D & 60 & NG & NY & 1991 & $\mathrm{CB}$ & US, D,V & $\begin{array}{l}\text { Construction and Term } \\
\text { Loan Agreement }\end{array}$ \\
\hline E & 60 & NG & MA & 1990 & $\mathrm{CB} / \mathrm{I}$ & $D, V$ & $\begin{array}{l}\text { Construction and Term } \\
\text { Loan A.greement }\end{array}$ \\
\hline $\mathbf{F}$ & 28 & NG & CA & 1990 & $\mathrm{CB}$ & $D, V$ & Term Loan Agreement \\
\hline G & 70 & $\mathrm{C}$ & Eastern & 1990 & CB & D & $\begin{array}{l}\text { Construction and Term } \\
\text { Loan Agreement }\end{array}$ \\
\hline$H$ & 80 & WC & WV & 1988 & CB & D & $\begin{array}{l}\text { Construction and Term } \\
\text { Loan Agreement }\end{array}$ \\
\hline \multicolumn{8}{|c|}{ Publicly Available Documentation Reviewed: } \\
\hline Piney Creek & 30 & wC & PA & 1990 & $\begin{array}{l}\text { Swiss } \\
\text { Bank }\end{array}$ & $\begin{array}{l}\text { D-MidAtlantic } \\
\text { V-Tampella }\end{array}$ & Official Statement \\
\hline Chambers & 260 & $\mathrm{C}$ & NJ & 1991 & $\begin{array}{l}\text { Swiss } \\
\text { Bank }\end{array}$ & $\begin{array}{l}\text { US-US Gen Co. } \\
\text { V-Bechtel }\end{array}$ & Official Statement \\
\hline Scrubgrass & 80 & WC & PA & 1990 & Nat West & $\begin{array}{l}\text { US-US Gen Co. } \\
\text { V-Bechtel }\end{array}$ & Official Statement \\
\hline $\begin{array}{l}\text { Midland Cogen. } \\
\text { Venture, L.P. }\end{array}$ & 1370 & NG & MI & 1990 & $\mathbf{P}$ & $\begin{array}{c}\text { US-CMS Midland } \\
\text { V-Various } \\
\text { Others }\end{array}$ & $\begin{array}{l}\text { Prospectus (Debt sold } \\
\text { after Project completion) }\end{array}$ \\
\hline
\end{tabular}

Fuel Type:

C: Coal

NG: Natural Gas WW: Wood Waste WC: Waste Coal
Lender Type:

CB: Commercial Bank

I: Institutional/Insurance

P: Public Issue
Owner Type:

US: Utility Subsidiary

D: Non-utility developer

V: Affiliate of Vendor Contractor to Project 
The loan agreements for ten of the twelve projects were executed (closed) at the start of project construction. These loan agreements provide for both construction and permanent financing for the project. Typically, the lender provides $100 \%$ of the funds budgeted for construction of the project, with a certain percentage of the loan repaid by equity in the event of a default during construction or at project completion. At project completion, the remaining balance on the construction loan "converts" to a permanent loan. For the two projects for which the agreement for construction financing was not available (Project $F$ and the Midland Cogen Venture), risk allocation and management provisions during construction were not assessed.

For 11 of the 12 projects in the sample (excluding the Midland Cogen Venture), the percentage of total project cost provided by equity or subordinated debt ranges from $7 \%$ to $25 \%$, with 5 projects between $10-20 \%$ and 5 projects at $20 \%$ or more.

Several private power projects have been able to raise part of their capital through tax-exempt bonds issued by local financing authorities. This source of capital is generally available when the project benefits the community is some way, such as resource recovery with a waste-coal project. Tax-exempt financing is desirable because its cost can be substantially below the cost of bank debt or bonds. The interest rate spreads vary but typically fall in the 1-3\% range. All of the projects in the sample that utilized tax-exempt bonds are supported by a letter of credit (LC) from a commercial bank (the LC bank). The LC bank "back stops" the project's obligation to the bond holders, by agreeing to pay the bond holders in the event project revenues are insufficient. The LC bank then looks to the project for repayments of any advances it makes under the LC. Most of the conditions precedent, covenants and default provisions are included in the LC bank documents, not the tax-exempt bond documents themselves (although the terms of the LC bank documents are summarized in the Official Statement). The credit review and loan documentation performed bv an LC bank is similar to what would be performed by a senior lender that is underwriting a transaction or making a loan for its own account.

In the sample, the term of the LC is much shorter (7-10 years) than the term of the tax-exempt bonds (22-30 years). The bond documents will typically require the LC to be renewed with a bank of similar credit quality prior to the expiration of the term of the LC, or, if not renewed, the bonds are subject to mandatory redemption (payment of principal in full, plus accrued interest).

The term of the senior debt for the projects without tax-exempt financing ranges from 11 to 18 years from the start of project operations.

The Midland Cogen Venture is unique in the sample in that it issued taxable bonds to the public after the project became operational. MCV is the first major private power project to raise debt capital in the public market. Standard and Poor's has just recently started rating the senior debt of private power projects, and has indicated that such ratings are "most appropriate" for projects 
that are operational. Public debt could become an important source of capital for private power projicts. $^{2}$

\subsubsection{Restrictions on Data Collection, Limitations on Results}

Collection of a representative sample of documents is difficult due to the proprietary nature of most agreements. As part of this study, several lending institutions were contacted to inquire as to their willingness to release documents for review. Universally, institutions would only release documents on the condition that project specifics be kept confidential. Unlike power sales agreements that are subject to regulatory review and are often in the public record, loan agreements are heavily negotiated documents that both borrower and lender are reluctant to make available for public disclosure. Both lender and borrower believe that negotiated loan terms embody certain competitive advantages they have in their business. In fact, confidentiality provisions are often included as part of the agreement.

As a result, the sample is limited to projects for which documentation could be acquired within the scope of the study, and is not necessarily representative of the industry as a whole, or, further, the "state of the art." Instead, the sample was reviewed to identify the mechanisms that are used in all or most of the sample to allocate and manage risks, and to identify more restrictive terms and conditions on a case-by-case basis.

All of the projects in the sample were financed on a non-recourse, project-finance basis, where the investors (debt and equity) look solely to the assets of the project and future project cash flows for their return on investment. In the private power industry today, almost all of the capital required for constructing a project is raised using the project finance structure. The private power industry is relatively young and is constantly evolving. As the private power industry matures, it is possible that developers will use vehicles other than the project-finance structure for raising capital, such as issues of public debt for project finance (like the Midland Cogen Venture) or issues of corporate debt or equity by development companies, where returns to investors are not solely dependent on the success of one project. ${ }^{3}$ Given that, it is worth noting that the protections provided to a lender in a non-recourse project financing (as described in this paper) may be quite different from protections provided in a recourse financing or corporate financing. Although we have not reviewed documentation for recourse or corporate financings, our experience would tend to indicate that provisions in those documents would be less strict because the lender looks to more than one project for repayment.

\footnotetext{
${ }^{2}$ MCV's publicly-issued senior bonds were rated BB + by Standard \& Poor's and BBB- by Fitch.

${ }^{3}$ For example, several companies have raised equity through public stock offerings (AES Corp., Destec, OESI, and others) and AES Corp. recently raised debt capital through a public offering of convertible subordinated debentures.
} 


\subsection{Limitations of Publicly Available Documentation}

For the projects in the sample where public information is available, some limitations should be noted. For each of the four, either the "Official Statement" or the "Prospectus" was reviewed. Neither of these documents is the actual loan agreement. These documents contain summaries of the relevant financing documents and the other relevant project documents. During the offering period for these securities, potential investors are invited to review the actual documentation. (In fact, the summaries are qualified in their entirety by reference to the actual project documents.) It is difficult to obtain the actual documentation after the initial offering of the securities, so the actual documentation was not reviewed for these four projects.

For the most part, however, the summaries contain enough information to generically describe the control mechanisms imposed by the lender on the borrower. In two cases, Official Sia'ements were available for projects for which the loan agreements were also reviewed (on the condition of non-disclosure). A comparison of the summaries to the actual documentation indicated that the summaries generally list terms and conditions, and were lacking primarily in details. ${ }^{4}$ For purposes of determining the minimum set of conditions imposed, these documents proved to be sufficient.

\footnotetext{
${ }^{4}$ For example, an Official Statement might indicate that the borrower is restricted from paying dividends or making distributions to partners or shareholders under certain circumstances. The actual loan documentation will specify exactly what those circumstances are, e.g., when reserves are not fully funded, when an event of default has occurred, when certain financial ratio tests are not met, etc.
} 


\section{Chapter 4 \\ A Typology of Loan Covenants}

\subsection{Introduction}

In this chapter we detail the procedures for managing the five specific risks of project development and operation. These are: (1) construction risk, (2) operating risk, (3) financial risk, (4) fuel risk, and (5) regulatory and environmental risk. In each case we begin with the conditions precedent, and then describe the kinds of restrictions and oversight provided by the loan covenants. We also describe default provisions briefly. ${ }^{5}$

\subsubsection{Construction Risk}

A lender engaged in non-recourse financing of a power project faces significant risks involved in the actual construction of the project. The lender primarily seeks to mitigate three risks:

(1) delays in the construction schedule,

(2) costs in excess of the construction budget, and

(3) operating performance below expected levels.

An occurrence of any one of these events may have an adverse impact on the project's revenues and therefore, debt service coverage. More often than not, the lender is unwilling to assume these risks and instead opts to allocate the risks to the contractor as much as possible.

All of the projects in the sample are constructed under the terms and conditions of a turnkey, fixed-price, date-certain construction contract, which requires the contractor to provide a completed facility meeting specific performance characteristics for a set price by a certain date. The contract includes a schedule with intermediate milestones with damages payable for delays. Progress payments are made to the contractor according to the percentage of work actually completed, with a certain percentage of the payment withheld (typically 5\%) until the project is successfully completed. The project owners take possession of the facility only after the passage of various performance tests, including damages associated with failure to meet performance guarantees (see Section 4.1.4). The contract also may include warranties to ensure reliability after some period of completion.

\footnotetext{
5 This paper is not intended to be a rigorous or exhnustive discussion of all of the issues and risks faced in a loan transection. Loen agreements for private power projects are legal documents that are prepared and reviewed by legal counsel, and a more comprehensive review would include a legal analysis.
} 
Ten of the twelve agreements in the sample provide construction financing, and their loan provisions dealing with management of construction risk are discussed below.

\subsubsection{Conditions Precedent Relating to Construction Risk}

All of the loan agreements require that various conditions be met (i) before the loan agreement is executed and construction begins (initial funding) and (ii) before subsequent construction drawdowns are made. These conditions are meant to establish, in advance, milestones or phases in the construction process that must be reached prior to advancing additional funds to the project. These provisions allow the lender to limit its exposure to losses in the event of failure and gives the lender considerable control over the construction process.

The following conditions precedent relating to construction risk are included in all of the loan agreements:

- Construction contract acceptable to lender in place prior to execution of the loan commitment, with acceptable liquidated damage provisions for delays and performance deficiencies. The lender will review damage payment levels to determine to what extent the lender is "kept whole" in the event of a deficiency (see Section 4.1.4 for further detail).

- Independent review by an outside engineering consultant prior to the start of construction, which would typically require a review of project design and engineering, construction schedule and budget (including contingency allowances), adequacy of permits, and assessment of geological or geotechnical hazards.

- An irrevocable commitment (ranging from cash collateral or a letter of credit to a corporate guarantee) from the developer to provide funds (i) upon a default in the construction loan, (ii) at a date certain if the project is not yet completed, or (iii) upon project completion. This commitment may be provided as a combination of subordinated debt and equity.

- Legal opinions as to the enforceability and legality of the construction contract, and assignment of the construction contract to the lender in the event the developer defaults on its obligations under the contract, so that the lender can cause completion of the project. 


\subsubsection{Oversight of Drawdowns and Change Orders by Lender and/or Independent Engineer}

In all of the agreements, fundings under the construction loan are limited so that the lender can limit its exposure should problems arise. Drawdown limitations allow the lender to influence project construction progress. When making a drawdown request, the developer is required to certify that no defaults have occurred and that no material adverse changes in project expectations have occurred.

All of the agreements require independent engineer approval of construction loan drawdowns, allowing for review of the progress of construction and assurances that the drawdown corresponds closely with actual construction expenditures. The drawdown is normally sized to allow the developer only enough funds to pay current costs under the construction contract, in line with the original construction budget.

All of the agreements require lender and/or independent engineer approval of change orders under the construction contract. This provides the lender with the ability to limit changes to the work scope that will (i) modify performance guarantees, (ii) increase the cost of the project, (iii) change the project schedule or (iv) make other modifications that might reduce the viability or reliability of the project.

Finally, the conditions precedent to the final drawdown for payment of any retainage under the construction contract and funding of reserves for project operations establish that construction is complete and that the lender has little or no exposure to further construction risks. All of the loan agreements require that the independent engineer certify that the construction is complete and that the performance requirements have been met.

\subsubsection{Requirement to Build to a Certain Standard}

Many of the loan documents include a provision that the project be built to a certain standard of quality, to provide further assurances that the facility will perform as expected and performance will not deteriorate rapidly. Rather than providing specific engineering and construction standards, most loan documents contain general guidelines such as "standard construction practice" or "good utility practice."

Provisions in other project documents provide similar assurances. For example, similar guidelines are specified in more detail in the construction contract itself. In addition, the power purchase agreement also may contain standards for construction quality. 
Across the sample, six of the seven loan agreements require that the project be constructed in accordance with some standard. ${ }^{6}$ One loan document specified "prudent utility practice." Two others simply required that the project be built to the "specifications detailed in the construction contract." The other three construction loan agreements required "sound building and engineering practice," "good and workmanlike manner," "generally accepted construction practice", and similar language.

The remaining agreement does not have this provision but requires that "substantial completion," as defined in the construction contract, occur prior to conversion to permanent financing.

\subsubsection{Liquidated Damage Provisions}

Loan documentation often has specific language which secures the lender's right to liquidated damage payments which may be payable as the result of deficiencies in the contractor's performance under the construction contract. These damage payments are separate from any similar requirement the project may have with the utility. Liquidated damages are normally intended to compensate for delays in completion or failure to meet performance criteria. The occurrence of either one of these conditions threatens project viability and expected debt coverage ratios.

Details on liquidated damages are generally contained in the construction contract, through detailed algorithms which establish the level of payments along with an appropriate ceiling.? Delay damages are often set to a level which will compensate the developer for the additional interest expense caused by a delay in completion. The lender will generally seek to use delay damages to pay interest accrued during the delay to preserve the expected capitalization of the project at completion and expected debt coverage ratios. The lender may also seek to use delay damages to pay any penalties incurred under the project documents as a result of the delay (e.g., under the power purchase agreement) to keep the documents in full force and effect.

Performance damages are set to compensate the developer for lost profits resulting from a deficiency such as reduced availability or output. The lender will generally seek to use performance damages to pay down the principal balance of the loan and to reduce scheduled repayments of principal pro-rata, to preserve coverages under a reduced revenue scenario. Alternatively, the lender may apply damages to reduce the maturity of the loan.

Construction contracts and assignments were not reviewed for this study, making it difficult to track the lender's control over liquidated damages. However, in all agreements where sufficient

\footnotetext{
6 The Official Statement summaries are silent on this provision.

7 The construction contracts for the projects in the sample were not reviewed for this study, so the variation in the magnitude of damages was not assessed.
} 
information was available, the lender controls the use of damage payments either through the "waterfall" (see Section 4.3.3) or by requiring mandatory principal payments on the loan.

\subsection{Operating Risk}

Operating risk is the risk that the project will not operate as reliably or efficiently as expected, or that operating costs will not be low enough relative to the revenue stream to maintain projected debt service coverage ratios. A large part of the lender's due diligence prior to making a loan commitment, is to review the expected performance of the project, in terms of both technology and contract pricing structures. The lender's goal in the loan documentation is to provide assurances that the project is operated as it was expected to be operated at the time the loan commitment was made, and that if the project does not operate as expected, either (i) steps will be taken to improve performance, or (ii) reserve funds will be available to make up any deficiencies.

\subsubsection{Conditions Precedent Relating to Operating Risk}

The lender's first step is to make sure that certain elements are in place prior to converting to a permanent long-term loan. All of the loan agreements require that the lender receive the following:

- Independent engineering review of the reasonableness of projections of revenues and operating costs for the project and verification of assumptions regarding plant output and consumption, at least over the term of the loan.

- Certification by the lender's independent engineer that performance tests required in the construction contract have been passed, or that required damages have been paid.

- Certification by an independent insurance broker that specified levels of insurance are in place and fully paid (including, typically, business interruption insurance, general liability insurance, and casualty insurance for catastrophic events such as fire and earthquake).

- Certification by the borrower (and in some cases, by an independent consultant) that all permits required for plant operations are in full force and effect, and that the plant is a qualifying facility or has the required FERC approvals (as applicable).

- Assignment of project contracts to the lender, so that in the event the developer defaults on its obligations the lender can step in.

- Provision for legal opinions as to the enforceability, legality and sufficiency of project contracts needed during the operating period. 
- Funding of initial reserves, if required.

Most of the loan agreements require that an operating agreement acceptable to the lender be in place prior to the start of construction. In all but one case, the operating agreement is to be in place prior to conversion to permanent financing. The exception is the Midland Cogeneration Venture. In that case, the project lessee also operates the project without a long-term operating agreement.

These conditions precedent are intended to provide further assurances to the lender that the transition from construction to operations will be successful. Difficulties in start up can often lead to "finger-pointing" between the construction contractor and the operations and maintenance contractor. Generally, O\&M contractors will be on-site several months prior to completion of construction, and construction contractors will provide performance guarantees for one year after completion, along with equipment warranties and guarantees provided by vendors. These warranties and guarantees allow the owner to look to the construction contractor for performance on individual pieces of equipment, rather than going to individual manufacturers. Details as to specific responsibilities of the construction contractor relative to the O\&M contractor and equipment vendors are typically included in the construction and O\&M contracts themselves, and have not been reviewed for this study.

\subsubsection{Restriction on Amendment/Replacement of Project Contracts, or Change in Contracting Parties}

In a private power project financing, the lender is lending solely against the strength of a system of contracts. During the credit review process, the lender spends considerable time and effort evaluating the project contracts, their pricing provisions and other terms, and the quality of the contract parties. Once comfortable that the contracts and the project participants provide an appropriate risk allocation and level of credit quality, the lender needs to be sure that the borrower will keep the contracts in place over the long term. Each agreement in the sample provides for some level of restriction on modifications to the project documents. An example of very restrictive language is as follows:

Borrower shall not enter into any amendment of, waive any of its rights under, terminate, or rescind any of the Related Documents [project contracts and other documentation, including insurance policies] or Governmental Authorizations [permits, approvals].

Most of the agreements are somewhat less restrictive, providing for amendments under certain circumstances, for example, so long as there is no "material adverse effect" on the project or on actual or projected debt coverage. Such provisions transfer some burden to the lender to demonstrate that a change is in fact prohibited under the terms of the agreement. Other less restrictive terms prohibit modifications to only the primary project contracts (financing documents, power sales, fuel, construction, operations and maintenance). 
Generally, these restrictions also would prevent a substitution of an alternative contracting party (such as a new operator). In a few cases, a covenant specifically restricts a change in contract parties without lender approval. In some cases, the utility may be involved in the negotiations concerning a change in project participants.

\section{Lender's Ability to Remove and Replace Project Operator}

In three of the agreements reviewed, the lender has some right to remove and replace the operator if performance is in some way deficient. In two of these cases, the project operator is an affiliate of the developer. The lender's concern regarding an affiliated operator is that either (i) the operator is not maintaining the project properly, or (ii) the operator is being paid too much money, and the developer has no incentive to replace the operator due to the affiliated relationship.

This provision is not universal across the loan agreements in the sample with operator/developer affiliations. In total, seven of the projects have such an affiliation. Payments to affiliated operators are often strictly controlled, and failure of the operator to meet its obligations under the operating agreement or bankruptcy of the operator is often a default under the loan agreement, providing a similar protection for deficient performance.

\subsubsection{Reporting Requirements}

Each of the loan agreements in the sample provides for some level of reporting to the lender as to the status of the project. At a minimum, the developer is required to deliver quarterly unaudited and annual audited financial statements for the project. Although the lender may not be able to take a specific action as a result of receiving an unfavorable report, these reports allow the lender to (i) monitor loan performance, and (ii) receive "early warning signals" on performance difficulties, and to anticipate problems. One also would expect that the requirement to deliver regular reports would tend to force the developer to keep a close watch on operations and attempt to fix problems as they arise, as it is always easier to deliver a favorable report rather than an unfavorable one.

The level of detail required in reporting varies. In the best case, the developer is required to deliver reports detailing project output, fuel consumption, unit prices of output and consumption, and an analysis and explanation of material variances from original projections or current budgets.

Special Notices. In all cases, the developer is required to deliver notices to the lender if certain events occur, such as (i) defaults under the loan agreement, (ii) defaults under any of the project documents, (iii) breach of permits or other governmental authorizations, and (iv) changes in law or other external events that may adversely affect the project. In most instances, such an event would resuit in an event of default, allowing the lender to take action. 
Reporting on Other Project Participants. In about half of the loan agreements, the borrower is required to deliver financial information on the primary project participants (typically the operator, power purchaser or fuel supplier) on a regular basis. Such a provision can be problematic for the developer as it may not have access to or control over preparation of such information. As an alternative, the developer may be required to notify the lender if there is a material adverse change in the financial condition of another project participant, and the developer has knowledge of it.

\subsubsection{Budget Oversight/Approval}

Because the lender is looking to future cash flows for repayment of the loan, the lender looks for assurances that the developer will in fact manage the project in accordance with projections made at the start of the loan term. Although the lender reviews these projections in detail before making the loan, the lender also seeks to limit the developer's ability to deviate from those projections once the project is operational, generally through involvement in the setting of operating budgets or approval of expenditures.

In all but one of the agreements, some level of lender oversight of expenditures is required. In the best case, the developer is required to submit an annual budget showing estimates of monthly revenues and operating expenses for the lender's (and, in some cases, the lender's engineer's) approval prior to the end of each fiscal year. Once the budget is approved, disbursements for expenses are limited to budgeted amounts (usially allowing for some small percentage overrun). (See also Section 4.3.2, Control Over Funds Flow). In the worst case, the developer is only required to deliver a budget to the lender with no specific provisions for following that budget. In more than half of the agreements, budget approval is required with some limitations imposed on the developer's ability to deviate from the budget.

The one exception is the Midland Cogeneration Venture. No specific budget approval mechanism is mentioned.

\subsubsection{Restriction on Other Businesses, Restriction on Transfer of Equity Interests, Change in Managing Partners}

All of the agreements require that the developer maintain the project's status as a single-purpose entity, solely in the business of generating and selling electricity (and steam) from the project as originally contemplated. The developer is restricted from purchasing other businesses, merging with other businesses, or generally entering into other activities that could, if unsuccessful, threaten the viability of the project.

About half of the agreements impose some level of restriction on sales or transfers of ownership interests in the project. Most of the agreements specifically restrict a change in project management (typically the general partner and original developer of the project). The lender's 
objective with such restrictions is to (i) maintain the developer's equity stake in the project and incentive to comply with loan terms and conditions, and (ii) keep existing management in place, as part of the decision to make a loan to a project is based on the track record, sophistication and experience of the developer/managing partners.

\subsubsection{Requirement to Operate to a Certain Standard}

In most cases, ${ }^{8}$ the developer covenants to operate and maintain the project to a certain standard, such as "in accordance with prudent practice," "consistent with prudent utility practice," or similar language. The operator will generally be bound by a similar provision in the operating and maintenance agreement.

\subsubsection{Overhaul Reserves}

Beyond regular operating and maintenance expenses, most projects will require periodic overhauls. The cost of such overhauls is generally factored into long-term cash flow projections. In the loan documentation, the lender will require the developer to make regular deposits (generally semi-annually after debt service payments) to an overhaul reserve account to provide assurances that sufficient funds will be available when overhauls are required. Ten of the twelve agreements provide for such set asides, with the amount of required deposits specified in the documentation.

The magnitude of set asides for overhauls will def end on several factors, and is often a heavily negotiated item. The technology, the operator's level of experience in general and with that technology, type of fuel, project operating mode (peaking or base loaded) and other factors will affect the level of reserves required. The purchasing utility may be a party to these negotiations. The lender's independent engineer will generally review the overhaul schedule for reasonableness prior to the start of construction, based on experience with other facilities. Because we have not examined the technical parameters of the projects in the sample, we have not attempted to assess the variability in the level of overhaul reserves required.

\footnotetext{
This covenant was found only in the actual loan agreements. The publicly-available summaries were silent on this provision.
} 


\subsubsection{Other Provisions}

Other provisions found in all of the agreements include a requirement to maintain insurance and pay premiums on a timely basis, and the lender's right to on-site inspections of the project and inspections of books and records.

Other provisions found in some but not all of the agreements include a requirement for periodic review of operations by an independent engineer and a prohibition on transactions with affiliates except on arms-length terms.

\subsection{Financial Risk}

Financial risk is that risk that, even when a project may be operating as expected, the project's capital structure or careless fiscal management may result in cash shortfalls to meet operating requirements. This has been a particular concern to lenders with project-financed private power projects, as projects are typically highly-leveraged. In general, more debt relative to equity makes a project more vulnerable to short-term fluctuations in revenue and cost streams.

Conditions precedent and financial covenants in ioan agreements are structured primarily to provide assurances that the project will have sufficient funds to meet (i) unexpected cash shortfalls, and (ii) scheduled periodic expenses. Provisions to prevent the developer from "siphoning" funds from the project are also included. In fact, in most agreements, the developer is given very little direct access to project revenues or control over the flow of funds. As described below, lenders have become quite sophisticated in structuring financial covenants, and these added protections help to assure that the project will be completed successfully and financial difficulties that can ultimately hinder project performance will be avoided.

\subsubsection{Conditions Precedent Relating to Financial Risk}

Most of the loan agreements require that debt service and/or other reserves be established out of construction loan proceeds or equity contributions prior to term loan conversion. In a few cases, the loan agreements provide for holdbacks of development fees or require standby equity commitments to fund future cost overruns.

\subsubsection{Debt Service and Working Capital Requirements}

All of the loan agreements in the sample have a debt service reserve requirement. In most cases, this reserve is initially funded by the lender out of construction loan proceeds. The purpose of the debt service reserve is to provide a cushion for payment of debt service during short-term periods of performance difficulties. This reserve allows the developer to continue paying debt service without causing a default under the loan agreements. After funds have been 
drawn from the reserve, first available cash flows will be used to replenish the reserve (see also Section 4.3.3, Control Over Funds Flow).

In their rating criteria for independent power projects, Standard \& Poor's states that the desired level of debt service reserves varies according to technology, overall level of project risk, and other factors, and that "low risk" projects should have reserves of six months' debt service to be considered investment grade. For the projects in the sample where sufficient information was available, debt service reserve requirements range from about three to nine months' debt service, in most cases sufficient to cover six months' debt service. In the sample, reserves are funded up front or out of available cash flows before distributions to owners (or a combination of both).

About half of the agreements have requirements for establishing and maintaining working capital reserves. The working capital reserve is generally funded through some combination of (i) proceeds of the construction loan, (ii) equity contributions at completion (or, alternatively, provision of a letter of credit), or (iii) out of project cash flows. Some earlier private power project financings overlooked the need for sufficient working capital to cover time lags between receipt of revenues under the power purchase agreement and payment dates on obligations under supply contracts (principally fuel). In most cases, electric utilities are required to pay for power purchases within 30-60 days of the monthly meter read, while suppliers often require payment on a 15:30 day basis. On a $\$ 100$ million project, this could lead to a working capital requirement of \$2-3 million to pay for a month's worth of fuel and other operating expenses while waiting for payments from the electric utility. ${ }^{9}$

\subsubsection{Control Over Funds Flow}

During the construction period, the lender controls disbursements of draws on the loan. During the operating period, the lender controls disbursements by restricting the developer's ability to make payments and other disbursements out of revenues received from electricity, and, as applicable, steam sales. The lender controls the flow of funds in three ways:

(1) by limiting the developer's access to project cash flows until all other project obligations have been satisfied through a "waterfall,"

(2) by restricting the developer's ability to take cash from the project under certain circumstances, and

(3) by limiting the developer to making only "permitted investments."

\footnotetext{
9 This simplified calculation assumes non-fuel operating expenses of $\$ 0.01 / \mathrm{Kwh}$ and fuel expenses of $\$ 0.02-$ $\$ 0.04 / \mathrm{kWh}$ (including transportation costs) for a $100 \mathrm{MW}$ project operating at an $85 \%$ capacity factor.
} 


\section{The "Waterfall"}

In all but one of the loan agreements, the developer is required to set up a trustee or custodial account that controls project cash flows. The developer directs major purchasers of project outputs (electricity, steam) to deposit payments directly to an account controlled by a trustee. The trustee then directs payments to project suppliers, project lenders, reserve accounts, and ultimately project owners according to a specific set of instructions. All of these accounts are pledged to the lender as part of the collateral for the loan. This set of accounts and instructions are commonly referred to as a "waterfall."

A typical waterfall structure is shown in Figure 4-1. This figure is an expanded version of what is included in Fletcher et al., 1991. First, revenues will be used to pay fuel and other operating expenses. Operating expenses are often limited to budgeted amounts that have been previously approved by the lender (see Section 4.2.4). Next, senior interest and principal payments are made. Next, reserve accounts are filled according to requirements in the loan documentation, and payments are made to subordinated lenders. Sometimes, other expenses, such as operating costs above budgeted amounts, or performance bonuses to operators, are paid only after reserve account requirements are satisfied. Finally, assuming other requirements are met (see below), any cash flow remaining is released to the developer.

Insurance and liquidated damage proceeds are also under the control of the lender. In the event of a loss covered by insurance, the loan agreements require that the developer first determine (in consultation with the lender) if the proceeds are sufficient to make repairs, and if so, repairs are made. In the event of a catastrophic loss (which is generally determined in consultation with the lender's engineer), proceeds are applied directly to pay down the outstanding balance of the loan. Proceeds from liquidated damages under the construction contract are generally paid directly to the lender for application to interest payments (delay damages) or principal payments (performance damages).

\section{Restrictions on Distributions/Dividend Payments to Owners}

Most of the agreements limit releases of cash flow to the developer under certain circumstances, even if cash flow is available and all reserves are filled. The lender uses these restrictions to hold back cash for future needs if the project appears to be in trouble. Cash hold backs also provide the developer with an incentive to improve projec' performance so that cash will ultimately be released. ${ }^{10}$

\footnotetext{
${ }^{10}$ In the event that the lender is able to move against the collateral, the lender would have a claim against any cash hold backs.
} 
In the loan agreements with restrictions on distributions, hold backs generally occur in two ways: (i) when actual or projected debt coverage ratios fall below a pre-determined level, and (ii) when a default has occurred in the loan agreement. ${ }^{11}$

Figure 4-1. Typical "Waterfall" Structure

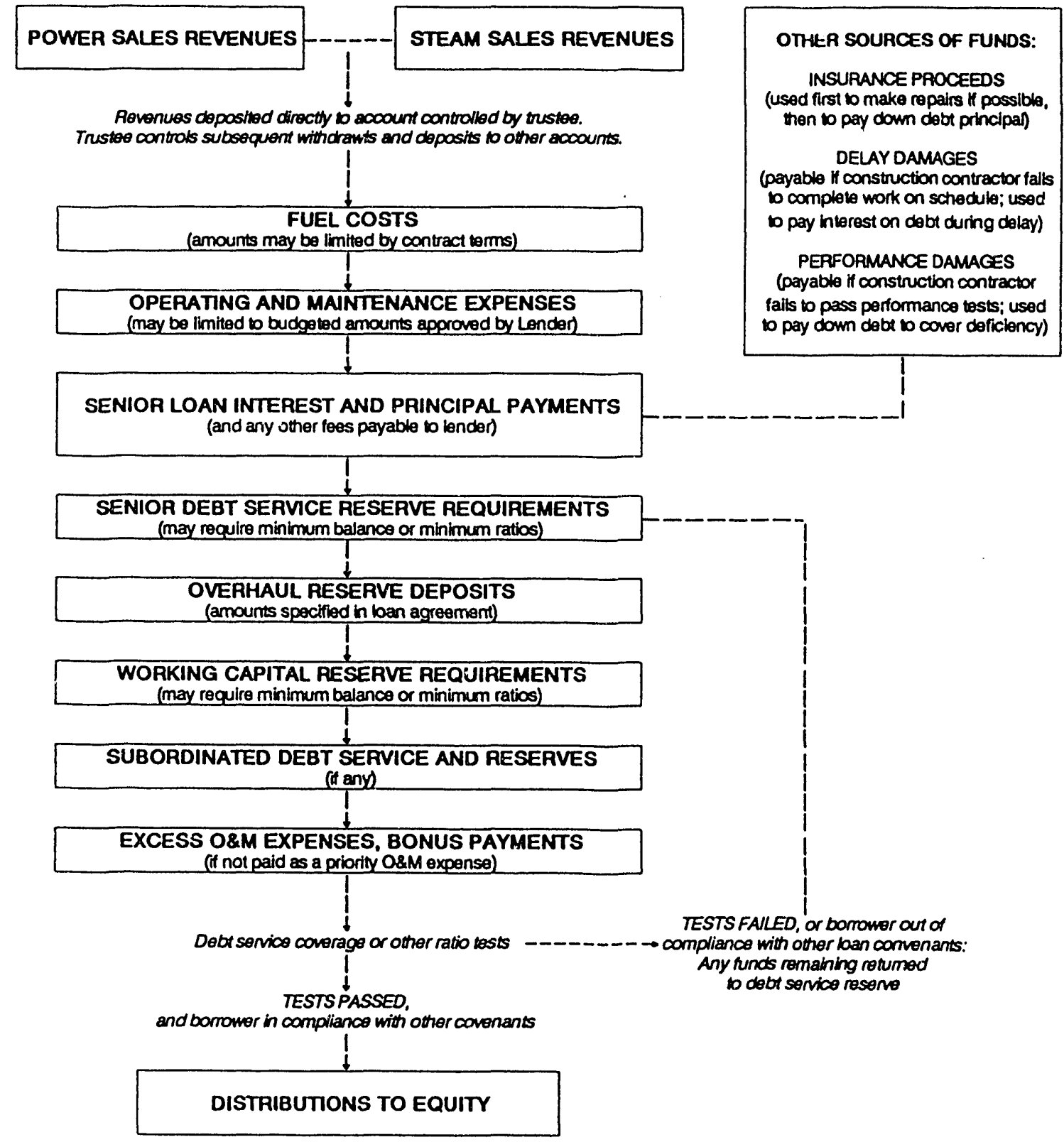

"Defaults can result from a variety of events in addition to failure to make payments on the loan when due, ranging from relatively minor violations of the loan agreement, such as failure to deliver a financial statement, to more serious problems such as loss of QF status or bankruptcy of a project participant. 


\section{Permitted Investments}

Where sufficient information was available, all of the agreements had a "Permitted Investments" covenant. ${ }^{12}$ This covenant restricts the developer from making any investments except for Permitted Investments, which are generally defined as high-quality, short-term government and corporate securities, and bank certificates of deposit. The primary purpose of this covenant is to prevent the developer from investing idle funds (including reserve fund balances) in speculative ventures. In cases where the flow of funds is controlled by a trustee, the developer will provide instructions to the trustee on where to invest funds held in various accounts, limited by the definition of permitted investments.

\subsubsection{Limits on Additional Debt, Liens, and Sale of Assets}

All of the agreements prohibit the developer from incurring additional debt. In some cases, additional debt is allowed if it is below a certain dollar amount or is sufficiently subordinated to the lender's debt. This prevents the developer from increasing financial risk due to higher debt service requirements. The developer is also required to maintain the lender's collateral to perfect the lender's security interest in project assets as required. Similar provisions prohibit the granting of additional liens on the assets of the project.

All of the agreements prohibit the developer from selling "all or substantially all" of the assets of the project. Some of the loan agreements prohibit selling "any" project assets.

\subsubsection{Interest Rate and Exchange Rate Risk Protection}

If applicable, the lender will require that certain financial risks that are not controllable by the developer are hedged, specifically, interest rate risk and exchange rate risk.

Only a few of the agreements in the sample have a clear provision for interest rate protection. From the information that was available for several of the agreements without such a provision, however, it was difficult to determine if there is a significant interest rate risk exposure.

Only one of the agreements had a clear exposure to exchange rate risk (due to the purchase of Canadian gas supplies). In that case, the developer is required to enter into a long-term currency swap acceptable to the lender.

\footnotetext{
12 Three of the Official Statement summaries did not address Permitted Investments. It cannot be determined if the loan agreements had such a provision or not.
} 


\subsection{Fuel Risk}

From a lender's perspective, one of the most vulnerable areas in a private power project is the potential squeeze between revenues under the power purchase agreement and the cost of fuel, resulting from eithe- (i) lack of sufficient supplies to meet production requirements, or (ii) fuel or transportation costs that are too high relative to the price of electricity. Lenders typically will not accept fuel price risks. The case of MCV, examined in Section 5.2.1 below, is a limited exception to this rule. The primary mechanism for insulating a loan from fuel risk is through structuring long-term contractual arrangements for fuel purchase and fuel transport that match the pricing terms in the power purchase agreement. As with the otiner project contracts, longterm fuel contracts are generally negotiated and executed before the lender finalizes the construction and term loan commitment.

In addition to contract structure, the lender will examine the strength of each of the contracting entities (supply and transport), the adequacy of damage provisions in the contracts, each entity's ability to meet its obligations over the term of the contract or in the event of a breach, its reputation in the industry and past performance with similar obligations, and its economic incentives to perform under the contract. Particularly where the pricing structure passes some or all of the fuel price risk to the supplier, the strength of the fuel supplier and adequacy of fuel supply is critical. The lender will review how the project's contract fits with the supplier's other obligations and the supplier's reserves and exploration plans. In some cases, reserves will be pledged to a project, and, in turn, pledged to the lender as security for the loan. Finally, the lender also will review the availability of alternative supplies and the project's ability to burn alternative fuels (both technically and within permit constraints).

Conditions precedent and loan covenants to manage fuel risk are structured to preserve and maintain the fuel arrangements that are in place before the lender commits to making the loan. As with operating risk, the lender seeks provisions that will provide early warnings on problems with fuel deliveries or prices, and the right to approve modifications to the contracts or the contracting parties should changes be required.

\subsubsection{Conditions Precedent Relating to Fuel Risk}

Most of the loan agreements provide for the following conditions precedent to reduce fuel risks:

- Fuel supply and transport agreements acceptable to the lender in place prior to the start of construction.

- Assignment of fuel supply and transport contracts to the lender, so that in the event the developer defaults on its obligations the lender can step in and preserve fuel deliveries. 
- Provision for legal opinions as to the enforceability, legality and sufficiency of fuel contracts needed during the operating period.

- Independent consultant review of fuel supply and transport arrangements, and the consultant's opinion as to the adequacy, reliability, and forecasted pricing of those arrangements.

A report by an independent consultant was more likely to be required for projects where gas deliveries depended upon sufficient supplier reserves or regulatory approvals for transport, or where sufficient debt coverage is dependent upon the accuracy of forecasts of the utility's avoided cost or fuel escalation rates. A review of fuel supply is often included in the independent engineer's scope of work.

Some of the loan agreements also required financial information on fuel suppliers and transporters.

\subsubsection{Restriction on Amendments to Contracts or Change in Contracting Parties}

As discussed in Section 4.2.2, each agreement in the sample provides for some level of restriction on modifications to the project documents. This provision covers fuel supply and fuel transport contracts.

\subsubsection{Reporting Requirements}

A few of the agreements require the developer to deliver financial statements on the fuel supplier and fuel transporter to the lender.

\subsubsection{Project-Specific Covenants for Fuel Risk}

In two agreements, the project's ability to transport the primary fuel supplier's gas to the project was not clear prior to the close of financing, as the necessary pipeline extensions or export approvals were not yet in place. In both cases, interim or back-stop gas supply and transport arrangements were in place at financial closing. In one case, the secondary supplier is required to keep the supply commitment in place until such time as the lender is satisfied that the primary gas supply can be delivered to the project reliably and at an acceptable price. The loan agreement requires for review of the primary transport arrangements by the lender's fuel consultant prior to the lender's approval of cancellation of the back stop agreement.

In the other gas-fired example, not all of the pipeline expansion approvals necessary for the transport of gas supplies to the project were in place at the time the loan commitment was made. To protect the lender from the risk that gas would not be delivered, the loan agreement provides 
for an increase in the interest rate, and ultimately an event of default, if alternative arrangements acceptable to the lender for gas deliveries were not made by a date certain.

\subsection{Regulatory and Environmental Risk}

Regulatory risk is the risk that a project will not obtain or stay in compliance with various permits, licenses and regulatory approvals, or that changes in law, including subsequent actions of regulatory bodies, will adversely affect operations or impose additional expenses. Environmental risk is the risk that regulations applicable to emissions, waste disposal or other activities will have an adverse effect on the costs of constructing, operating and maintaining the project.

\subsubsection{Conditions Precedent Relating to Regulatory and Environmental Risk}

All of the loan agreements include the following conditions precedent to reduce regulatory and environmental risks:

- Certification by the developer (and sometimes an independent consultant) that all permits, approvals, licenses and other necessary governmental authorizations have been acquired prior to the start of construction or prior to the start of operations, as applicable.

- Review by the lender's independent engineer of the project's ability to operate within requirements imposed by permits and other governmental authorizations.

- Evidence that the project is a qualifying facility or has the required FERC approvals (if applicable).

- Provision of legal opinions as to the legality and sufficiency of required governmental authorizations.

Most of the agreements also require a review of the site by an environmental consultant for the existence of hazardous substances, and, if found, a remediation plan.

\subsubsection{Compliance with Permits and Governmental Authorizations, QF Status}

All of the loan agreements require the developer to comply with the provisions of all permits and other governmental authorizations, and to acquire any new permits or approvals as required by law. All of the loan agreements require the developer to maintain the project's status as a qualifying facility (as applicable). 


\subsubsection{Changes in Law, Resistance to Regulatory Change}

Most of the agreements provide for an event of default if a change in law or regulation has an adverse impact on the viability of the project (such as stricter emissions limits). In two cases, the loan agreements go one step further and require the developer to actively resist or protest such changes (through lawful actions). In one case, the developer is required to fund a special reserve account to pay for capital expenditures that are anticipated to be required as the result of future amendments to federal or state air emissions regulations.

\subsection{Default Provisions}

All of the documents specify that an event of default occurs if the developer violates a provision of the loan agreement, with violation of certain provisions subject to certain grace periods. An event of default also occurs if the developer defaults on other debt. Certain other events are also defaults, including (i) bankruptcy of the project or (ii) bankruptcy of the general partner of the project.

In most cases, a default also occurs if the project loses its QF status, if adverse regulations are enacted, if the project is out of compliance with permits, or if a judgement against the project is made, among other events.

In some cases, the default provisions allow the lender to broaden its "sphere of influence" over other project participants. In about half of the loan agreements, bankruptcy of a project participant (fuel supplier, constructor, operator) or a material adverse change in the financial condition of a project participant is a default. Such a provision tends to force the developer to replace that participant with a new participant and a new contract that is acceptable to the lender. 


\section{Chapter 5 \\ Implications of Debt Leveraging in Electric Power Supply}

\subsection{Introduction}

This chapter returns to the three questions raised in Section 15107 of S2166, and addresses them in light of what we have learned from our study of project finance. Inevitably the discussion will involve issues outside the domain of project finance. In some cases, the analysis of project finance can address the question directly. This is particularly true of the question concerning reliability. In other cases, notably the impact of private power on the utility cost of capital, the relationship is more tangential. In this case, factors such as regulatory policy toward cost recovery of private power payments and the magnitude of the utility construction program are critical. Particular issues in the power purchase contract between the utility and the private producer are also significant. The third question, capital structure and competitive advantage, is illuminated to some degree by the structure of project finance. Other important factors are the financial policy of the utility, i.e. determinants of the marginal cost of capital, and re-financing strategies of the private power producers.

The discussion in this chapter is intended to be an overview of these issues. The goal is to identify those areas where firm conclusions can be drawn and those that are more difficult. We try to identify what kind of information is relevant to a given issue, what are the most important "first-order" effects, and what are "second-order" effects. Inevitably, should state utility commissions grapple with these questions, they will view them in the light of local conditions and information.

The plan of this chapter is to state the competing arguments pertaining to each issue, review what specific features of the structure of private power are relevant to the issue and how other regulatory matters are involved. In each case, we identify what specific features of private power contracts, utility practice or regulatory practice will determine specific conclusions in individual cases.

\subsection{Reliability Effects of Leverage}

The basic concern underlying this issue is the belief expressed by some parties that private producers do not have the obligation to serve that franchised utilities have, and therefore they will be less reliable (Jordan, 1991). Formulated at this general level, the reliability issue has little to do directly with leverage. Having more or less debt does not affect the presence or absence of obligations. The connection between leverage and reliability, therefore, must be drawn more concretely. One potential connection is that high debt leveraging is itself irresponsible behavior, and an indicator that financial manipulation is the dominant motivation 
of the producer. In the extreme case, large amounts of debt might suggest that the developer could simply "take the money and run." We believe that this version of the reliability/leverage story is highly implausible.

The more significant connection involves the producer's ability to cope with adversity. All else equal, a highly leveraged project has a narrow margin between revenues and costs. Unanticipated operating problems may eliminate that margin and cause the project to cease operation. Utilities and customers who place reliance on such projects will incur costs if operating problems cause projects to fail. The bulk of our discussion concerns coping with adversity. Before we turn to that issue, however, we will argue that the "take the money and run" scenario is not a serious issue.

The discussion of financial risk in Section 4.3, in particular the "waterfall" (Figure 4-1), illustrates the generic impossibility of a "take the money and run" failure. By this we mean, that once a project has reached the stage of financing, a system of controls has been established that limits developer access to the capital investment devoted to the project. This kind of control is a generic feature of project finance, regardless of the venture to which it is applied (Kensinger and Martin 1988). The corporate finance structure typically allows more managerial discretion, which may be good if circumstances are complex and potentially unprecedented. It may be bad if discipline is weak, and the potential for inefficiency is great. In the project structures reviewed in Chapter 4, the "waterfall" is a universally used mechanism which restricts the flow of funds available to developers until all project obligations, including reserve accounts, have been funded. Therefore, the ability of developers to divert the funds raised for investment to nonproject purposes is essentially zero. The only exception to this would be cases of fraud, where developers managed to manipulate supplier invoices in ways that escaped detection. Such exceptions are, of course, possible under corporate finance structures as well, and have little to do with the degree of leverage.

Clearly, financial failure can occur before a project has raised the capital for investment in equipment and construction, but then the losses will be primarily the developer's equity investment. To the extent that ratepayers may suffer opportunity costs from awarding contracts to developers that turn out to have non-viable projects, milestone deposits can be used to limit these losses. Many states and utilities now require deposits from developers as "earnest money" that encourages responsible behavior and that will be forfeited if projects do not develop as expected (see, for example, NJBPU 1988). Thus "planning risk," as it affects ratepayers, can be mitigated by milestone deposits.

These arguments suggest, therefore, that the more serious case of project reliability problems involves defaults due to operational difficulties. This is a leverage issue to the extent that debt obligations decrease the margin between revenue and cost streams, therefore making projects more vulnerable to disruptions. It does not matter too much whether the difficulties are due to increased costs or reduced revenues. An operational problem, for example, will have both effects; revenues decline due to poorer performance and repair or maintenance expenses are required to restore performance. 
It is precisely these contingencies that are anticipated by the requirement for debt service reserves. In the contract sample surveyed in Section 4.3.2, the typical debt service reserve was sufficient for a six month period of non-performance by the generator. For conventional generation technology, this is probably an adequate period, barring catastrophic events. In addition, reserves for ordinary and routine maintenance must be maintained as well as overhaul reserves for scheduled maintenance costs. These practices are much more explicit and contractually binding than the corresponding procedures used by electric utilities. For example, utility bond indentures also have maintenance cost requirements (Howe 1987), but these are not tied to specific powerplants. Therefore, one utility powerplant may not receive the kind of routine maintenance required in project financing, whereas another may get even more.

Finally, in the event of an operational problem that results in a leveraged project falling short on meeting its debt obligations, it is incorrect to assume that the result is project "failure." Defaults under loan agreements do not imply that the project will immediately, or ever, cease operation. Conversely, as discussed in Chapter 2, a default allows the lender to step in and take actions to correct problems that have occurred. In a project financing, the lender is looking solely to the assets of that single project and the future revenue streams it will produce for repayment, giving the lender every incentive to keep the project operating even under adverse scenarios. The lender will take steps to replace project operators, restructure fuel supply arrangements, and make improvements or repairs to the project before shutting down the project and selling off equipment. Increased leverage in a project and the resulting decrease in margins does not, in and of itself, increase the risk that the utility and its customers will not receive the power that it expected to receive under the terms of the contract.

We illustrate several reliability issues that may arise in project financing by examining two projects in our sample for which we have bond prospectuses: Scrubgrass and Midland Cogeneration Venture (MCV).

\subsubsection{Midland Cogeneration Venture (MCV)}

MCV reveals the types of reliability issues that can arise with relatively conventional technology. A distinguishing feature of this gas-fired cogeneration project is its uncharacteristic mismatch between the variable payment structure in its power purchase agreement and the underlying variable costs. The energy payment stream for MCV is based on the buyer's avoided coal -based fuel costs. MCV has arranged a portfolio of gas supplies based primarily on contracts with escalation formulas that will closely approximate the expected trajectory of avoided fuel costs. The linkage, however, is only approximate, and has the potential to diverge in the later years of the contract. The sensitivity of the project's operating margin to this mismatch and to basic operational uncertainties is quantified in the feasibility report on the project included in the bond prospectus (Stone and Webster 1991). Table 5-1 summarizes various sensitivities for the year 2001 , the last year of the senior debt. 
Table 5-1. MCV Operating Margin Sonsitivity

\begin{tabular}{lccc} 
& Base Case & Sensitivity & Impact (million \$) \\
\hline Availability & $90 \%$ & $-1 \%$ & -4.6 \\
Heat Rate & $9100 \mathrm{Btu} / \mathrm{kWh}$ & $+150 \mathrm{Btu} / \mathrm{kWh}$ & -4.3 \\
Dispatch & $65 \%$ & $75 \%$ & -4.1 \\
Energy Price & 3.10 cents/kWh & $-5 \%$ & -6.3 \\
\hline
\end{tabular}

MCV has an expected margin, i.e. the difference between revenues and expenses including debt service, of $\$ 24$ million in 2001. Each of the sensitivities listed in Table 5-1 has a material effect on that margin. Even their combined effect, however, would not lead to a debt service default. In the case of fuel price risk, it would appear that an energy price $20 \%$ below expectations could lead to a default. Of the four factors listed, only the first two are under the control of the project management. Availability and heat rate are results of the operations and maintenance procedures adopted by management. The projected availability is well within the range of reasonable expectations for gas turbine technology. The heat rate is also in the reasonable range for cogeneration projects.

The feasibility study is unique in one respect, because it reports actual operational results. The MCV bond offering is unusual because the project had more than one year of operating experience when the financing occurred. The early operational record shows that engineering expectations have been nearly fulfilled, but that certain "shake-down" problems require attention. These include subtle problems involving the division of responsibility among the construction contractor, the equipment vendor and the O\&M contractor. In this case the equipment vendor and the O\&M contractor are affiliates of the same corporation. The general "division of responsibility" issue was identified in Section 4.2.1 above. During initial operation of MCV, certain repairs to equipment were performed by the construction contractor, while other were performed by the vendor/O\&M contractor.

In summary, although MCV is a highly leveraged project whose profitability has more market and regulatory risks than is typical in the private power industry, it also has managerial procedures and incentives to assure long-run reliability. The structure of contracts among the participants has already worked to resolve early operational problems, and long term maintenance procedures have been negotiated to maintain expected levels of performance. These issues are handled in a straight forward fashion in this case because the technology involved is conventional; therefore posing no particular or unusual risks. Therefore, even though the project has relatively narrow operating margins, safeguards are built into the overall fnancial structure to help assure long run operating reliability. 


\subsubsection{Scrubgrass}

The Scrubgrass project is based on circulating fluidized bed technology for the combustion of waste coal. As such, it falls into the category of riskier and less simple technologies as assessed by bond rating agencies (Standard and Poor's 1991a). 'he project was financed in part by tax exempt bonds (VIDA 1990). As indicated in Section 3.2, a bond prospectus (or "Official Statement") does not disclose project documents in much detail. Further, the Scrubgrass prospectus does not have the level of engineering feasibility assessment that the MCV prospectus contains. There are rather detailed characterizations of the incentive structure in the construction contract, particularly for performance standards, which indicate a serious concern with technical risk management.

In the discussion of liquidated damages for construction risk (Section 4.1.5), we argued that the usual standard applied to these covenants was that both delay damages and performance damages were related to debt service, but in different ways. For delay damages, the standard means that these damages must cover extra interest charges associated with later commercial operation than expected. For performance damages the goal is to reduce loan principal by an amount that will preserve the original financial coverage ratios expected under the higher performance. The effect of both conditions on technically risky projects will be felt through the capital intensity of the projects. Generally speaking innovative technology has higher capital costs and lower operating costs than the corresponding low risk alternative. In the case of coal combustion, this can be seen by comparing Scrubgrass with Chambers, another coal project, but one which uses conventional combustion. The total financed cost of Scrubgrass is $\$ 200$ million for $82.5 \mathrm{MW}$ of capacity, for an average cost of $\$ 2424 / \mathrm{kW}$. Chambers, which also sold bonds, has a total financed cost of $\$ 549$ million for $260 \mathrm{MW}$ of capacity, or $\$ 2111 / \mathrm{kW}$ (NJEDA 1991). The capital cost differential would be even greater if an adjustment were made for the costs of pollution control devices (selective catalytic reduction) which Chambers has that are not typical for coal plants.

Financings for technically riskier projects will be structured so that the technology risk is allocated to those parties that can best manage and absorb that risk. For example, the ability of these projects to attract substantial amounts of debt financing depends to a considerable degree on the reputations of the firms involved in construction and operation of the facilities (Standard and Poor's 1991a). The ability of developers to finance Scrubgrass is a signal that the firms involved were thought capable of managing the technical risks even in the presence of substantial leverage. Another relevant factor in this case is that the project construction and O\&M contractors are affiliates of the developer. This kind of integration of functions helps align the profit incentives of the participants to manage the technical risk. In general, projects with more technology risk can be expected to have higher equity requirements, higher reserve requirements (debt service and maintenance) and tighter provisions in terms of warranties, guarantees, performance requirements, and penalty provisions. 


\subsubsection{Performance Incentives in General}

It is not necessary for power projects to be capitalized in the project financing framework for a system of performance incentives to be established. There has been an increasing trend toward the development of incentive mechanisms for regulated utilities independent of competition. In the electric utility industry, many of these incentives have focused on power plant performance, particularly for baseload projects (Brown, Einhorn and Vogelsang 1989; Joskow and Schmalensee 1986).

In principle, it is possible to impose the same performance incentives on utility generation projects as are imposed upon private power producers. In practice, it does not appear as if the same standards are used. Although insufficient data exists to make the comparison rigorously, the minimum availability threshold in private power contracts, $80 \%$ on an annual basis, is approximately the average performance for utility plants (Kahn 1991; Joskow and Schmalensee 1986). Moreover, there is reason to believe that regulatory commissions adopt performance incentives for utilities that are less efficient than expectations. This proposition has been shown in a recent statistical study which found a significant predictive relationship between higher than expected cost and the subsequent adoption of incentive mechanisms by the regulator (Berg and Jeong 1991). Furthermore, the same study found that no significant total cost reductions could be detected for firms subject to specific performance incentives after these measures had been mandated. Thus, for regulated utilities performance incentives in one dimension may have the effect feared by Joskow and Schmalensee, namely that the costs of meeting the target would not be subject to much control, and could therefore easily exceed the benefits. While this evidence is certainly not conclusive, it does tend to confirm the general picture of economic efficiencies in project finance as opposed to the potential inefficiencies of utility regulation.

\subsubsection{Summary}

In summary it appears that the case for a strong causal linkage between a high degree of leverage and reliability problems is weak. There is even some evidence that the causality could be just the opposite, namely high leverage induces closer management attention to reliability and therefore superior performance to the behavior of regulated utilities. The record is still too limited to prove this latter case. However, our survey of project finance does indicate that a strong system of controls is typically established in the financial structure of private power projects to assure a high probability of performance. The high threshold requirements for availability typically contained in power purchase agreements encourage this attention because capacity payments are at risk.

The project finance structure is not impervious to reliability problems. There can be ambiguities or complexities in the contractual relationships among the construction contractors, equipment vendors and O\&M contractors. These may present particular problems for newer and riskier technologies. The conservative nature of the financial community has not constrained private 
power developers to avoid new technology, and the benefits of its success will accrue to developers, constructors, and operators who have been willing to accept and manage that risk.

Of all the policy questions raised in S2166 about debt leveraging, the reliability issues are probably the most straight-forward. As long as lenders must be repaid, there will be strong incentives to perform reliably.

\subsection{The Impact of Purchased Power on the Utility Cost of Capital}

This issue has received considerable exposure from the credit rating agencies, who were among the first and most credible people to identify the potential equivalence between the capacity payment obligation contained in private power purchase contracts and other non-standard forms of debt. In this discussion we divide the question into two parts. First, we ask what it is about private power purchase contracts that may make them "debt-equivalent." To address this question we consider two issues: (1) the features of the contract itself, and (2) the cost recovery mechanisms available to the utility for these purchase costs. The second question we discuss here is the "compared to what?" issue. Private power contracts do not exist in a void. Utilities have a number of options for meeting incremental resource need, of which these contracts are only one. Answers to the question of how purchased power affects the utility cost of capital will depend on the unique circumstances facing individual utilities. We will try to outline the nature of this dependence.

Particular features of project finance have relatively little to do with the issues addressed in this section. The main relationship between the financial structure of private power projects and these questions arises at a broad and general level. This is the "demand risk transfer" argument. There are variations on the basic argument (Perl and Luftig 1990; Raboy 1991). Briefly, the line of reasoning proceeds in the following fashion:

(1) The private producer has a purchase contract which eliminates uncertainty about whether his product can be sold and at what price.

(2) It is the elimination of these uncertainties which makes highly leveraged project financing feasible.

(3) In reality the risk is not eliminated. The demand for power at the contract price may not materialize.

(4) The power purchase contract simply shifts this risk from the project to the utility.

(5) Absorbing risk without compensation raises the utility's cost of capital.

(6) Therefore, the existence of project financing means that the utility cost of capital must have increased.

The main points of contention in debates over these issues seem to focus on Step 4 in the stylized argument just outlined. Once Step 4 is accepted, then some version of Steps 5-6 follow reasonably enough. Similarly, no one seriously argues that Steps 1-3 are incorrect. Therefore, our discussion, which is basically an examination of Step 4 , focuses on what assertions about 
shifting the demand risk really mean, and whether alternative resource strategies really offer any alternatives.

The debt-equivalence notion means that private power payments are fixed costs that reduce the flexibility of the utility and diminish its capacity to adapt to unfavorable conditions. To investigate this notion, we ask first whether these costs are really fixed, and second what determines whether they are or are not an added burden of inflexibility during times of adversity.

\subsubsection{What Makes for Debt-Equivalence?}

The extreme case of debt equivalence is the "take-or-pay" contract. This is an obligation upon purchasers to make payments to "sellers" regardless of whether any product or service is actually delivered. Demand for the product or service is irrelevant in this situation. It is easy to imagine that "take-or-pay" contracts could be simply re-labelled as "fixed obligations." This relabelling just makes more semantically obvious that "take-or-pay" contracts cannot be distinguished from debt.

Proponents of the demand risk transfer argument assert that the capacity payment obligation is essentially unconditional. A closer examination shows that power purchase contracts do not have "take-or-pay" terms. It is common to refer to the conditional nature of the utility purchase obligation as a "take-and-pay" contract. Conditionality is a matter of degree. Broadly speaking the more conditionality found in these contracts, the less like debt they appear. Conditionality can take a variety of forms, some of which are explicit in the contractual arrangements, some of which reflect the broader regulatory environment in which the purchasing utility functions. We discuss each of these in turn.

Power purchase contracts allocate a variety of risks between the private producer and the utility. The more of these that the utility itself bears, the more debt-equivalence in the purchase arrangement. First, we will examine contract clauses. These determine the limits on payments to private producers. Contracts are not the entire story, because there is ultimately a set of procedures for recovering contract payments from utility ratepayers. If these recovery mechanisms are conditional, then risk resides with the utility. Hence we must also examine cost recovery procedures.

\section{Contract Clauses}

Power purchase contracts can be stringent or lenient in the terms and conditions defining nonprice relationships. Where the terms are lenient, the utility is absorbing risk. The broad range of contractual practices have been surveyed elsewhere (Kahn 1991). Here we highlight the most important clauses that are relevant to demand risk. 
We will define three different time perspectives that are relevant to the measurement of demand risk and its allocation. The first period is the interval between the conclusion of a power purchase agreement and the first commercial operation of the project. We will call this the precommercial period. The second period is the commercial operation period. Finally, the third period, which occurs after the second, we will call the termination period. There are a variety of ways that utilities can limit demand risk during each of these periods.

During the pre-commercial period there are two ways that the utility can limit or control demand risk. The most common of these, and the weakest alternative, is a "drop dead date" for commercial operation. The utility can hedge its uncertainties about future need for power by only allowing a certain interval between signing the contract and initial service from the project. These intervals will vary with the technology involved, being longer where the permit and construction process is expected to be longer. It is not uncommon for developers to seek extensions or deferrals. The usual practice is that such extensions, if granted, do not also allow for price indexation. The stronger alternative is an explicit buy-out option. If the utility seeks cancellation for economic reasons, i.e. demand has not materialized as originally expected, the contract is terminated with a payment to the developer. Such payments would compensate for sunk costs and sub-contractor cancellation penalties if any. One utility has recently built the buyout option into its Request for Proposals. Bidders will be evaluated in part on how small a buy out price they will accept (NEP 1992). The use of buy-out options is still quite limited, but as concern with demand risk increases, its use can be expected to grow in frequency.

During the commercial period, the ability to limit demand risk is much smaller. There is a range of contract clauses that address performance standards, which amount to conditionality on the "take and pay" obligation. We have discussed thresholds on generator availability in the reliability discussion in Section 5.1 above. There are other clauses that also are performance related. One of the most common of these involves capacity testing. Private producers must demonstrate their ability to meet contract delivery ratings on an annual or semi-annual basis. Some contracts invoke a lenient standard regarding this requirement. Such forbearance is the opposite of conditionality, and so implies more of a "take-or-pay" quality than the stringent contracts. Similarly, there are dispatch limits in many contracts which limit the operational flexibility of utilities. These also amount to a shift of demand risks to the utility which can be costly (Kahn et al. 1992).

The termination period may be initiated by lack of performance. By this stage of developments, the payment of capacity charges has stopped in the majority of cases. Even here, however, there are greater and lesser degrees of forbearance associated with how long the developer has to solve whatever operational problems may have led to non-performance. By allowing the developer more flexibility, the utility is essentially giving them "re-start" options. The value of such an option to the utility may be negative.

Termination may also be invoked by the utility for economic reasons through the "regulatory out" clause. This says that if for any reason or at any time the regulatory commission refuses to allow the costs of the contract to be recovered from utility customers, then the utility's 
obligation to make payments terminates. This clause passes the risk that power is uneconomic from the utility to the private producer, and therefore increases the conditionality of the contract and decreases its debt-equivalence.

Some contracts are silent or ambiguous on the issue of regulatory disallowance. There are others which have "anti-regulatory out" clauses. Virginia Power, for example, has several contracts which state that payments will continue, at least for a certain number of years, even if the costs are disallowed by the regulator. The motivation of such a clause is to provide credit support for the debt of the private producer. Such support, however, is a contingent liability for the utility, and certainly contributes to the debt equivalence of these contracts. Surprisingly, this particular contract clause was not explicitly identified as one of the several contributory elements underlying the down-grading of Virginia Power's debt by credit ratıng agencies (Standard and Poor's 1991c).

\section{Cost Recovery Mechanisms}

The regulatory out clause highlights the important role of cost recovery procedures in the determination of whether the contingent liabilities in contracts lie with the utility itself, or whether they are passed on to the consumers by the regulator.

One indicator of where the liability ultimately resides is the type of rate hearing in which these issues are raised. It is usually argued that if contract costs are dealt with in fuel adjustment proceedings as opposed to general rate cases, then implicitly there is less risk of cost recovery. Even analysts who maintain that private power contract capacity payments are debt-equivalent acknowledge that if cost recovery is automatic, then there is no debt-equivalence (Rosenzweig 1991). In practice, however, it is difficult to know in advance when cost recovery is automatic. Just because the issue may arise in an adjustment-type proceeding rather than a general rate case is not an infallible indication that scrutiny will be less and toleration greater than otherwise.

An important counter-example to the notion the fuel adjustment proceedings are "easy," is the disallowance case involving Southern California Edison Company (SCE) and its QF affiliate Kern River Cogeneration Company (KRCC). The California Public Utilities Commission began an investigation into the reasonableness of SCE payments to KRCC and other QF affiliates of SCE as part of the normal fuel and purchased power review. The investigation escalated into a significant and protracted adjudication when the utility resisted the Commission staff's request for documents relating to the corporate structure of KRCC and the history of its contractual negotiations with SCE. The issues were eventually segregated from the rest of the adjustment proceeding. Ultimately, the CPUC found that the terms and conditions of the KRCC contract were too lenient compared to those which should have formed the basis for payment, and therefore disallowed $\$ 48$ million in capacity payments (CPUC 1990). Similar issues associated with affiliate QF transactions continue to be the subject of special investigation. SCE's parent corporation has indicated that it expects to settle all of the related issues on terms equivalent to a $\$ 250$ million disallowance (SCECorp 1992). 
This story is as much or more about the risks of affiliate transactions as it is about fuel adjustment proceedings. One moral of the story is that the substance of transactions is more important for cost recovery than the form of the regulatory proceeding in which they occur. The other important lesson is that affiliate transactions raise the spectre of self-clealing abuse. The only other cost recovery disallowance for private power also involves an affiliate transaction, ramely the relationship between MCV and Consumers Power. Regardless of how the MCV pricing issues are resolved before the Michigan commission, they raise questions about the riskiness of MCV's bonds (Fitch Investors Service 1991a). Placing these risks on MCV, however, means they are not placed on the utility.

More broadly, the prognosis for cost recovery is influenced by the background conditions associated with project selection, regulatory approval of that process, and the degree to which a particular contract may deviate from any established norms of process or content. The regulatory out clause does not exist in a vacuum. If it is part of a contract that conforms with state policy toward private power procurement, then the likelihood of subsequent limitations on cost recovery is small.

\subsubsection{Compared to What?}

The debt-equivalence question is only one half of the larger cost of capital issue, and by some measures it may be the smaller half. By treating debt-equivalence in isolation, we neglect the question of alternatives; i.e. what would the utility do in the absence of a private power purchase?

An argument made by representatives of the private power industry is that demand risk is always borne by consumers, and therefore the existence of private power contracts does not represent a risk transfer (Naill and Sharp 1991). As a first approximation, demand risk is borne predominantly by consumers. On the margin, however, the allocation of some demand risk can fall on the utility. Cost disallowances associated with "excess capacity" are the most prominent example of cases where demand risk falls on the utility and its shareholders. There have also been cost disallowances for imprudent long term inter-utility purchases (CPUC 1989).

In practice, it is most desirable to frame the cost of capital impact question in the particular circumstances of individual utilities. There are clearly cases where long term purchases from private producers can lower the utility's cost of capital. One example where this principle was accepted involves the contract between Nevada Power Company (NPC) and a private power project known as Nevada Sun-Peak. NPC has a fast growing service territory which requires the construction of a relatively large amount of new generating capacity despite aggressive DSM programs. NPC negotiated a contract with private developers to construct a $210 \mathrm{MW}$ peaking project. One element of the cost basis used in the contract price was an adjustment for the financing cost to NPC if the utility had to construct the facility itself (NPSC 1990a, 19906). The idea is that the additional financing burden of this construction would have raised NPC's 
financing cost for the remainder of its construction budget. Avoiding the construction would avoid the associated financial deterioration and its costs.

The Sun-Peak case does not provide a clear record of exactly how the extra financing cost of construction was or should be incorporated into a pricing arrangement. The decision of the Nevada Public Service Commission is only qualitative. In circumstances where the utility was not already committed to a large construction program financed primarily with external capital, it is less clear whether a long term purchase contract would have the same effect that was claimed in this case.

It is reasonable to expect that the cost of capital impact issue will arise generically in "build versus buy" decisions that regulatory commissions will be addressing in the future. The usual setting for such decisions will involve a financially strong utility facing competition for limited capacity need from private producers. In several recent cases resembling this situation, regulatory commissions have not found that cost of capital impacts were particularly decisive. The Florida Public Service Commission, for example, granted a certificate for utility construction, but specifically rejected assertions that private power contracts would impose debtequivalent costs on the utility (FPSC 1992). Similarly, in two Maryland cases utilities have argued that a "debt-equivalent cost" be imposed on the evaluation of a private power alternative to utility construction. In both cases, the hearing officer explicitly rejected this notion, although the final commission orders were framed in ways which did not address the issue explicitly (PSCM 1991a,b; 1992a,b).

There are clearly a range of other settings in which the cost of capital impact issue might arise. A theoretically correct analysis of this issue would be conducted with a realistic representation of the actual financial situation of the particular utility, the financial implications of utility plans to meet future need, and some consistent account of the kinds of "debt equivalent" features that private power contract altematives would impose. This ideal framework will be rather difficult to implement practically. Simple rules of thumb may be more likely to emerge. If, for example, the utility project and the private power project were roughly similar, i.e. same technology and capacity, then neither could be expected to have a different impact than the alternative. If the utility were to argue credibly that its own DSM programs were the alternative to a private power project, and that these programs required no external financing, then perhaps some kind of debtequivalent adjustment could be argued. There is certainly no agreement about how such adjustments should be made, because there is no agreement about how to measure debtequivalence even though there is probably an effect of this kind. The credit rating agencies have different approaches (Fitch Investors Service 1991b; Standard and Poor's 1992). 


\subsubsection{Summary}

The cost of capital impact is probably the most indeterminate of the three topics raised by Section 15107 of S2166. While it is relatively easy to conclude that there may be something to the notion of debt-equivalence, it is difficult to find a perspective from which to assess its relative importance. In the short-run, it is unlikely that it will play a major role in state policy toward private power. In the longer run, as the issue of market share in generation gets more competitive, cost of capital questions may merge increasingly with larger strategic questions about the role of vertical integration. If utility ratebases decline substantially, then the problem of diminishing equity will eventually have to be confronted. The long run aspect of this issue is a subject for future research.

Cost of capital issues in utility regulation have always had a major judgmental element. With the growth of the private power industry and the questions raised by the debt-equivalence argument, the role of judgment is unlikely to diminish.

\subsection{Capital Structure and Competitive Advantage}

The discussion in the previous section brought out the underlying issue of a struggle for market share between private producers and franchised utilities. This struggle forms the background for much of the policy debate surrounding debt leveraging. In this section we address the question explicitly by asking if project financing in some way tilts the competitive struggle unfairly. This is clearly the perception of the private power industry's critics.

There has been a good deal written about the question of capital structure (Raboy 1991; Perl and Luftig 1990; Conway and Hausker 1991; Hausker 1991; Naill and Dudley 1992; NIEP 1991). We will summarize the stylized facts that form the basis for this discussion.

(1) Project finance typically uses a lower fraction of equity (and a higher fraction of debt) than utility corporate finance.

(2) The tax deductibility of debt lowers its cost.

(3) The cost of equity and the cost of debt are higher for project finance than for utility corporate finance.

(4) Project finance debt typically has much shorter maturities (15 years) than utility corporate debt (30 years).

(5) Project finance loans typically require debt service reserves.

There is no controversy about Facts 1-3, although there are substantial differences in the numerical estimates made for project finance debt fractions and equity costs. There is little agreement about proper way to account for Facts 4 and 5, including whether these are even relevant factors. 
In this section we will concentrate on two elements of project finance that have not been examined in the previous discussion. These are: (1) the role of sub-ordinated debt in project finance, and (2) the financial cost of short loan maturities (i.e., Fact 4). The first issue shows that there are important subtleties associated with the classification of financing instruments as either debt or equity. The second issue turns out to be the dominant effect with regard to competitive advantage in financing. It favors the utility corporate finance structure. Finally, we observe that the utility's marginal capital structure may be quite different than its average capital structure. For competitive analysis it is the marginal structure which is important.

Consistent with the existing literature on the subject, the following sections include stylized calculations using simplified assumptions. These calculations are intended to illuminate some of the issues that are under discussion in the current debate. A more rigorous analysis would include several other factors and a range of plausible assumptions for key variables. Our purpose here, however, is not to definitively quantify "competitive advantage," but rather, to highlight those factors that are more and less critical to the debate.

\subsubsection{Subordinated Debt}

In Section 3.1, we distinguished subordinated debt from senior debt in our description of the capital structure of the project sample. Here we explain in greater detail the logic behind this classification and some to the complexities associated with this form of capital. Hybrid financing instruments, like subordinated debt, are different from senior debt or equity. On balance, their costs and priority of payment are closer to equity. The fixed interest rate, mandatory principal payment, and tax deductibility are more like debt.

Most subordinated debt is roughly the project finance equivalent of preferred stock. It is an intermediate form of security between pure equity and senior debt. The main difference between sub-ordinated debt and preferred stock is that the former is still a loan and therefore the interest payments are tax deductible, whereas preferred stock dividends are not. Like preferred stock, sub-ordinated debt typically plays a small role (about $10 \%$ ) in the overall capital structure. The cost premium associated with subordinated debt, however, can be quite large. We will illustrate the role of subordinated debt in the capital structure of project finance by calculating the weighted average cost of capital (WACC) on an after tax basis in Table 5-2 below. This table is similar to calculations of others, relying on Facts 1-3 above. We use the following expression for WACC,

$$
W A C C=w_{e} * c_{e}+w_{d} * c_{d}(1-t)
$$

where $\quad \mathrm{w}_{\mathrm{c}}=$ portion of equity in the capital structure,

$c_{c}=$ cost of equity,

$w_{d}=$ portion of debt $i$ the capital structure,

$c_{d}=$ cost of debt,

$\mathrm{t}=$ tax rate. 
Table 5-2. Capital Structure and WACC

\begin{tabular}{|c|c|c|c|}
\hline & $\begin{array}{c}\text { Corporate } \\
\text { Finance } \\
\text { Case A }\end{array}$ & $\begin{array}{l}\text { Projec } \\
\text { Financ } \\
\text { Case B } \\
\end{array}$ & Case C \\
\hline 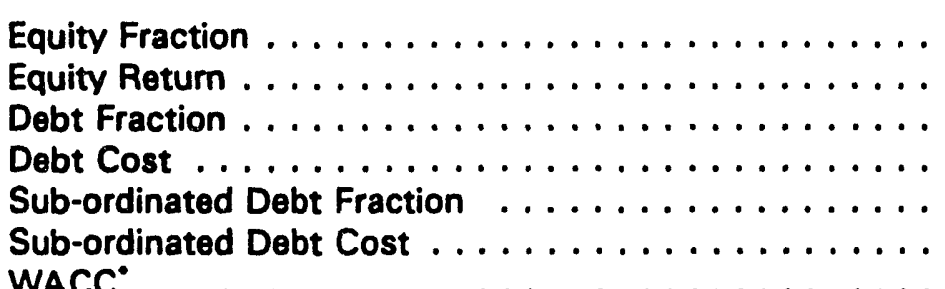 & $\begin{array}{r}50 \% \\
12 \% \\
50 \% \\
9 \%\end{array}$ & $\begin{array}{r}20 \% \\
16.5 \% \\
80 \% \\
10 \%\end{array}$ & $\begin{array}{l}10 \% \\
22 \% \\
80 \% \\
10 \% \\
10 \% \\
15 \% \\
8.47 \%\end{array}$ \\
\hline 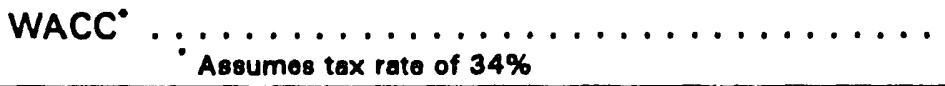 & $8.97 \%$ & $8.58 \%$ & $8.47 \%$ \\
\hline
\end{tabular}

Case $\mathrm{C}$ in Table 5-2, involving subordinated debt, classifies this instrument as debt because of tax deductibility. We will argue below that economically it is more like equity.

Table 5-2 shows what is generally concluded in the discussion of this subject, namely that project finance capital structures can produce a lower WACC than what is typical for the capital structure of regulated electric utilities. As in all exercise of this kind, slight changes in the assumptions can expand or narrow the magnitude of the differences. The assumptions used in Table 5-2 are reasonably "centrist", and counter examples exist on both sides. Project finance senior debt is $1 \%$ more costly than utility bonds; utility equity returns are $3 \%$ more expensive than utility debt. For our purposes, the role of subordinated debt in Table 5-2 is important. Under the numerical assumption used, it has a small impact on the WACC. At higher tax rates (some analysts include the effect of local property taxes), the spread among the WACCs in these three cases will grow.

It is important to notice that Table 5-2 shows that there is a declining marginal value of additional debt. While one could characterize Case $\mathrm{C}$ as a "90\% debt" capital structure, the marginal impact of the sub-ordinated debt shows that it is in many ways a substitute for equity. By increasing the prior claims on project cash flow, sub-ordinated debt raises the risk, and therefore the cost of the project equity. We assume a 22\% return for Case $C$ as opposed to only $16.5 \%$ for Case B. The cost of the sub-ordinated debt in Case C lies approximately half-way between the cost of the senior debt and the equity return. It is close to the equity return in Case B.

While we make no claims for the absolute value of these estimates, the basic lessons of these calculations are clear. First, additional debt raises the cost of equity. Perl and Luftig make this point when arguing for the "debt-equivalence" of private power contracts. It is no less true for project finance. Second, sub-ordinated debt is a very close substitute for equity. Therefore, we count it as part of the contingent capital in Section 3.1. Regulators who are concerned about high leverage project finance should become sensitive to the distinction between senior and subordinated debt. Finally, sub-ordinated debt does not have a large impact on WACC because it is high cost compared to senior debt. 
Once again, many of the policy debates over project finance issues are conducted at such a high level of generality (and/or obscurity) that some of the basic facts about this kind of finance have been lost in the argument. The next issue we discuss also illustrates the same general point.

\subsubsection{The Cost of Shorter Loan Maturities}

This subject is essentially Fact 4 from the list above. We will show in this section that the cost associated with shorter term debt is a significant competitive disadvantage for project finance, and that the magnitude of this effect is typically larger than any cost advantages emanating from a lower WACC.

The basic quantitative relations here are familiar to anyone who has compared 15 year with 30 year home mortgages. The payment is higher for the shorter term loan than the longer term loan where the principal is the same. Our case also involves differences in WACC as well as the amortization period. We illustrate the dominant role played by amortization period numerically by using the capital recovery factor (CRF) as a means of expressing the combined cost of return on capital (i.e. WACC) and the return of capital. ${ }^{13}$ The standard expression for CRF is given by

$$
C R F=\frac{R(1+R)^{n}}{(1+R)^{n}-1}
$$

where $\quad \mathrm{R}=$ the return on capital, i.e. WACC, and $\mathrm{n}=$ the amortization period.

In Table 5-3 we show how shorter amortization periods for project finance result in substantially higher annual fixed charges by comparing CRF for 15 year project finance with 30 year corporate finance over a range of assumptions about differences in WACC. The effect is modulated when 20 year loan maturities are used for project finance.

Case 1 in Table 5-3 corresponds to Case $C$ in Table 5-2 above. For Case 2 we use a substantially lower WACC, which reflects the very high leverage cases discussed by Raboy. In each case we look at 15 and 20 year loan maturities. The amortization burden of 15 year debt imposes a cost on project finance that is $2.8-3 \%$ greater than corporate finance. When 20 year debt is considered, costs are roughly comparable, with only small disadvantages for project finance.

This financial effect is different from the concept of economic depreciation used by Raboy. His analysis uses the same depreciation rate for both kinds of finance to estimate competitive advantage. From a social perspective, it is likely that the rate of depreciation will be independent

13 This is known as sinking fund depreciation. 
Table 5-3. Capital Recovery Factor



of ownership or financial structure. But from a private cost perspective, which is the orientation that is important for competitive analysis, the ownership and financial structure is crucial. Naill and Dudley incorporate the effect of loan maturity in their cash flow models, but then express the capital charge rate on a 35 year basis when they compare utility and IPP financial costs. This results in a small disadvantage for project finance. The reason for their result is that the last 20 years of their comparison involve minimal IPP costs.

Both of these approaches are approximations to a social cost calculation. Raboy assumes that the social depreciation rate is the same as the financial amortization rate. Naill and Dudley are clearly aware of differences in amortization requirements, but seek to normalize financial flows to the operational lifetimes of facilities. Neither of these approximations addresses the question raised in Section 15107 of S2166, which is the private competitive position of utilities and private suppliers. By this standard, the small WACC advantage of project finance is offset by the larger amortization burden of short loan maturities. On balance, however, there is no clear and generic advantage for either form of finance.

\subsubsection{Utility Marginal Cost of Capital}

The discussion of the capital structure issue has focused predominantly on the project finance side. Apart from the long term bonding capability, however, there may be additional financial advantages (or in some cases constraints) on the utility side of the competition. The key question is what the utility's marginal source of finance may be. The usual analysis is, on the capital structure side at least, an average calculation. It is assumed that the utility replicates on the margin its average capital structure. The costs of capital are assumed to be marginal costs.

In practice, the utility may have a marginal source of capital that differs from its average capital structure. In the debt equivalence literature, there are arguments that the utility's marginal cost of capital is all equity (Rosenzweig 1991). At the opposite extreme, it has been observed that during major multi-year construction cycles electric utilities work down their equity by raising debt disproportionately (O’Connor, Olson and Keenan 1991). 


\subsubsection{Summary}

The project finance structure is sufficiently different from utility corporate finance that simple comparisons can be misleading. Hybrid financing instruments like sub-ordinated debt are difficult to classify as debt or equity. On balance their costs and negotiation rights are more like equity. The fixed interest rate is more like debt. The weighted average cost of capital (WACC) is typically somewhat lower for project finance than for corporate finance because of greater leverage. Project finance usually involves both higher debt costs and higher costs of equity than corporate finance. Differences in WACC are heavily outweighed by the financial burden of short loan maturities. Project finance imposes a capital charge rate disadvantage compared to utility corporate finance because the debt must be repaid so much more quickly. This burden of amortization does not reflect differences in economic depreciation, but simply an expensive capital market constraint. Finally, any assessment of competitive financing advantage must examine not only the structure of project finance, but also a reasonable estimate of the utility's marginal capital structure. On the margin, the utility's capital structure can be quite different from its average capital structure.

\subsection{Future Directions}

The issues analyzed in this chapter will be re-visited by state regulatory commissions. We anticipate that issue $\# 2$, the capital cost impact of long term purchases, will be the one where most attention will focus in the long run. The reliability and competitive advantage questions are more clear cut, and probably less important than the questions raised by the "debt equivalent" arguments. Project finance has powerful incentives for reliability and does not appear to confer any capital cost competitive advantage, at least as currently practiced. The debt-equivalence issues, on the other hand, are difficult to formulate precisely and pose substantial quantification problems. Nonetheless, they are likely to become an important focus of the market share struggle between regulated utilities and private power producers. 


\section{Acknowledgements}

The work described in this report was funded by the Deputy Undersecretary for Policy Planning and Analysis, Office of Electricity, Coal, Nuclear and Renewables Policy, of the U.S. Department of Energy under Contract No. DE-AC03-76SF00098. The authors would also like to thank the following individuals: Kevin Kelly and David Meyer, U.S. Department of Energy, Robert Egan, Maryland Public Service Commission, Tom Gibian, Goldman, Sachs and Co., Karl Hausker, Senate Energy Committee, John Jurewitz and Mary Simpson, Southern California Edison, Keith Martin, Chadbourne \& Parke and William Chew, Standard \& Poor's. 


\section{Glossary $^{14}$}

Acceleration: Process by which lender moves to collect immediate and full payment of the loan. Usually occurs sometime after defaults have occurred.

Assignment: Lenders usually require the assignment of all major project documents as security for the loan.

Change Orders: Requests to materially alter terms or participants of project documents, most typically referring to changes in the construction contract.

Collateral: Assets of the project and its owners (land, plant, bank accounts, partnership interests, contracts, etc.) pledged to the lender as security for the loan.

Conditions Precedent: Conditions which must be met to the lender's satisfaction prior to closing a loan, receiving subsequent fundings of the loan, or conversion to a long-term loan, etc. (such as delivery of a satisfactory engineer's report to the lender).

Construction Loan: Loan advanced prior to the conversion date, which is used for the planning, design, construction, start-up and initial operation of the project. The loan typically matures upon the earlier of (i) an event of default, (ii) project completion, and (iii) a date certain.

Conversion: Process by which terms and obligations of the construction loan are extinguished and replaced by the term loan upon project completion.

Covenants: Specific agreements, generally as to business practices, which are carefully negotiated between the borrower and lender and are effective throughout the term of the loan. Affirmative covenants describe actions which are required while negative covenant describe actions which are prohibited.

Coverage: Generally used as a measure of a project's or company's ability to pay debt service. The debt service coverage is the ratio of cash operating margins (revenues less operating expenses) to debt service (interest plus principal) over some period of time. Higher coverages indicate a greater cushion or margin for error in the project's ability to make timely debt service payments.

Credit Quality: The ability of a project or company to meet its obligations and sustain operations, particularly during periods of adverse economic and industry conditions. Factors to be considered include (among others) financial strength, reputation in the industry and in the

\footnotetext{
14 The definitions for these terms apply only in the context of this report. These definitions by no means should be used or construed as legal definitions.
} 
business community, extent of competitive advantage, expected future performance, and terms of contracts with suppliers and purchasers.

Default: Events and occurrences where the borrower, through some action or inaction, violates one or more covenants or conditions of the loan agreement.

Draudowns: Limited advances of funds under the loan, typically a construction, working capital, or development loan. Typically used in order to make payments directly to construction contractor or other project participants. Loan normally has conditions precedent to each drawdown to enable lender to "suspend" further fundings, thereby reducing losses in cases of failure.

Equity Commitment: Commitment by borrower or other party to contribute a significant portion of junior capital to project capitalization. Commitment is normally made prior to the start of construction with the contribution normally required to be advanced upon completion of project, or may be seized upon an event of default.

Final Acceptance: Event which occurs when the construction is complete and all performance tests are passed (or waived).

Grace Period: Period of time during which borrower or other participant can be out of compliance with covenants or other contracts and lender or others can take no action. Usually given for less serious offenses to allow time to "work things out."

Guarantee: An agreement to satisfy obligations or make payments on debt on behalf of another party.

Legal Opinion: An opinion formally rendered by an attorney with substantial qualification and recognized expertise in the subject matter.

Liquidated Damages: Payments required to remedy a default in performance under the project documents (i.e., power sales agreement, steam supply agreement, ground lease, construction contract, fuel supply agreement, etc.). Most typically found in the construction contract. Two general types are delay damages and performance damages. Delay damages compensate for increased interest expenses and foregone revenues resulting from missing the completion date. Performance damages replace foregone revenues resulting from a failure to meet targeted project performance.

Maturity: Point in time when an obligation is terminated. The time at which a promissory note or loan becomes due.

Non-recourse Financing: A form of financing where the lender cannot seek recourse on obligations outside of the entities and assets defined in credit and security agreements. 
Official Statement: Document issued by a local financing authority that describes the bonds to be issued by the authority to raise capital for a project. The Official Statement describes the project, the project participants, the associated contracts, and the terms and conditions of the bonds and other financing documents. Similar to a bond or stock prospectus.

Permitted Liens: Pledges of security interest in the project's assets which are permitted under the terms of the loan agreement. These are usually small deposits supplied for contractors, retainers, small mechanic liens, etc. The loan agreement generally allows a ceiling on the aggregate amount of permitted liens.

Project Documents: The set of major contracts which define the project. These will typically include the construction contract, the power purchase agreement, the ground lease, the operations and maintenance agreement, the fuel supply and transportation agreements, the steam sales agreement, and the waste disposal agreement. The lender usually has assignment of all of these contracts. Other documents may cover the supply of consumables.

Construction Contract: Requires contractor to build, test and ensure proper performance of the facility. These are usually fixed-price turnkey contracts with provisions for delay and performance damages (see liquidated damages). The facility's ownership is normally transferred to the borrower after milestones indicating near completion are achieved.

Power Purchase Agreement: Determines operating characteristics and pricing of electricity production by the facility that is sold to the purchasing entity, usually a utility, an industrial facility, or both.

Ground Lease: Project document between the borrower and the owner of the real estate forming the site of the project which describes the terms and conditions of the title and land use. The ground lease will often include language to limit the lender's exposure to losses and liability due to CERCLA or other statutes.

Operations and Maintenance Agreement: Describes terms and conditions related to the operation and maintenance of the facility by a contractor. Pricing terms may be structured to provide incentives for the contractor to maximize the performance of the facility.

Fuel Supply and Transportation Agreements: Describes terms and conditions related to the fuel supply and transport arrangements secured by the project. Increasingly, a family of contracts is required for service covering multiple parties (commodity, storage, transportation) between the fuel producing properties to the burnertip or boiler.

Steam Sales Agreement: Describes terms and conditions related to the supply of steam produced for consumption by adjacent or nearby industrial facilities. For cogeneration projects, a main concern in these contracts is that the project maintain its status as a Qualifying Facility under the Public Utilities Regulatory Policies Act of 1978. 
Waste Disposal Agreement: Describes terms and conditions related to the removal and disposal of hazardous and non-hazardous waste produced by the plant. Particularly important for coal-fired plants and increasingly important for natural gas-fired plants with extensive emission controls.

Remedies: Actions lender can take against the borrower in case of a detault.

Representations \& Warranties: Statements regarding the project and the participants that the borrower certifies as being true at the time they are certified.

Reserve Accounts: Accounts held to provide for foreseeable contingencies. Typical reserve accounts include operations and maintenance (or overhaul) accounts, working capital accounts, and debt service accounts. These are often required to be filled with available project cash flows, before equity distributions are made (see Figure 4-1).

Security Agreement: Document granting the lender a security interest in the collateral. These documents will describe the collateral and the lender's rights and interest in each or all of the collateral.

Subordinated Loan: Loan advanced by another lender for a portion of the total project debt which is higher risk since the right to repayment is junior to rights of the senior lender. Subordinated lenders are typically precluded from many remedies to collect repayments until senior obligations have been met.

Term Loan: Loan which is effective between the conversion date and the end of the amortization period (maturity).

Title: Instrument that provides evidence of the extent of perfect or imperfect ownership of a property or asset.

Waterfall: Description of the flow of funds between accounts from receipt of revenues to debt service and equity distributions (see Figure 4-1). The term "waterfall" is used as project revenues are used to fill accounts in order of priority, and cash is not deposited in lower priority accounts until higher priority accounts are filled. 


\section{References}

Berg, S. and J. Jeong, "An Evaluation of Incentive Regulation for Electric Utilities," Journal of Regulatory Economics v.3, no. 1 (1991) 45-56.

Brown, L., Einhorn, M. and I. Vogelsang, "Incentive Regulation: A Research Report," Federal Energy Regulatory Commission 89-3, 1989.

California Public Utilities Commission (CPUC), Decision No.89-02-074, 1989.

California Public Utilities Commission (CPUC), Decision No.90-09-088, 1990.

Conway, W. and K. Hausker, "Financial lssues in PUHCA Reform," U.S. Senate Committee on Energy and Natural Resources, March, 1991.

Fabozzi, F. and I. Pollack (eds.), Handbook of Fixed Income Securities, 2nd ed., Dow-JonesIrwin, 1987.

Fitch Investors Service, "Midland Funding $\mathrm{Co}_{3} .$. I," Corporate Finance/Public Utilities Special Report, September 24, 1991 a.

Fitch Investors Service, "Independent Power Charges Up," Corporate Finance/Public Utilities Special Report, October 28, 1991 b.

Fletcher, P. D., Esq. and J.A. Anderson, Esq., "Basic Concepts of Project Finance: Risk Allocation and Management in the Current Market," Milbank, Tweed, Hadley \& McCloy, 1991.

Florida Public Service Commission (FPSC), Order in Docket No. 910759-EI, 1992.

Hausker, K., "Comments on 5/29/91 ERC Report on IPP's and Debt Leveraging," U.S. Senate Committee on Energy and Natural Resources, August, 1991.

Howe, J., "Credit Analysis for Corporate Bonds," in Fabozzi, F. and I. Pollack (eds.), Handbook of Fixed Income Securities, 2nd ed., Dow-Jones-Irwin, 1987.

Jordan, D. , "The Hidden Threat," Public Utilities Fortnightly v.127, no.5 (March, 1991) 27-29.

Joskow, P. and R. Schmalensee, "Incentive Regulation for Electric Utilities," Yale Journal on Regulation v.4, no.1 (1986) 1-49. 
Kahn, E., "Risk Allocation in Independent Power Contracts," LBL-30065, Lawrence Berkeley Laboratory, Berkeley, CA, April 1991.

Kahn, E., C. Marnay and D. Berman, "Evaluating Dispatchability Features in Competitive Bidding," IEEE Transactions on Power Systems v.7, no.3 (1992).

Kensinger, J. and J. Martin, "Project Finance: Raising Money the Old-Fashioned Way," Journal of Applied Corporate Finance v.1 (1988) 69-81.

Midland Cogeneration Venture Limited Partnership, Prospectus \$999,905,607 Midland Funding Secured Lease Obligation Bonds, 1991.

Naill, R. and W. Dudley, “IPP Leveraged Financing: Unfair Advantage?” Public Utilities Fortnightly v.129, no.2 (January, 1992) 15-18.

Naill, R. and B. Sharp, "Risky Business? The Case for Independents," The Electricity Journal v.4, no.3 ((April, 1991) 54-63.

National Independent Energy Producers, "The Reliability of Independent Power: Operating, System, Planning, Fuel and Financial," September 1991.

Nevada Public Service Commission (NPSC), Opinion and Interim Order in Docket No. 90-390, 1990a.

Nevada Public Service Commission (NPSC), Final Order in Docket No. 90-390, $1990 \mathrm{~b}$.

New England Power Company and Massachusetts Electric Company (NEP), Request for Power Supply Proposals, April, 1992.

New Jersey Board of Public Utilities (NJBPU), Stipulation of Settlement in Docket No. 8010687B, 1988.

New Jersey Economic Development Authority (NJEDA), Official Statement $\$ 100,000,000$ Exempt Facility Revenue Bonds (Chambers Cogeneration Limited Partnership), 1991

O'Connor, P., W. Olson, and G. Keenan, "PUHCA Reform: Exploding the Myth of Deregulation," Palmer Bellevue Corporation, September, 1991.

Perl, L. ad M. Luftig, "Financial Implications to Utilities of Third Party Purchases," The Electricity Journal v.3, no.9 (November, 1990) 24-31.

Public Service Commission of Maryland (PSCM), Proposed Order of Hearing Examiner in Case No. 8201 and Case No. 8052, 1991 . 
Public Service Commission of Maryland (PSCM), Stipulation and Agreement in Case No. 8201 and Case No. 8052, $1991 \mathrm{~b}$.

Public Service Commission of Maryland (PSCM), Proposed Order of Hearing Examiner in Case No. 8241 Phase II, 1992a.

Public Service Commission of Maryland (PSCM), Order No. 69938 in Case No. 8241 Phase II, $1992 \mathrm{~b}$.

Raboy, D., "Risk Shifting and Its Consequences in the Electric Power Industry: PUHCA Changes and Independent Power Development," May, 1991.

Rosenzweig, M., Testimony on behalf of Baltimore Gas and Electric Company, Public Service Commission of Maryland Case No. 8241-Phase II, July, 1991.

Smith, C. and J.Wamer, "On Financial Contracting: An Analysis of Bond Covenants, Journal of Financial Economics v.7 (1979) 117-161.

SCE Corp, 1991 Annual Report, 1992.

Standard \& Poor's, "Independent Power Project Finance Rating Criteria," Standard \& Poor's Rating Criteria, October 17, 1991 a.

Standard \& Poor's, “MCV Tests Public Market for Independent Power," Standand \& Poor's CreditWeek, October, $1991 \mathrm{~b}$.

Standard \& Poor's, "Virginia Electric \& Power Co. Downgraded," Standard \& Poor's CreditWeek, December, $1991 \mathrm{c}$.

Standard \& Poor's, "The Role of Covenants in Ratings," Standard \& Poor's CreditWeek, February 3, 1992a.

Standard \& Poor's, "Credit Issues for Investor-Owned Utility Purchasers," Standard \& Poor's CreditWeek, May, $1992 \mathrm{~b}$.

Stone and Webster Management Consultants Inc., "Feasibility Report for the Midland Cogeneration Venture," in Midland Cogeneration Venture Limited Partnership, Prospectus \$999,905,607 Midland Funding Secured Lease Obligation Bonds, 1991.

Venango Industrial Development Authority (VIDA), Official Statement $\$ 105,600,000$ Resource Recovery Revenue Bonds (Scrubgrass Project), 1990. 

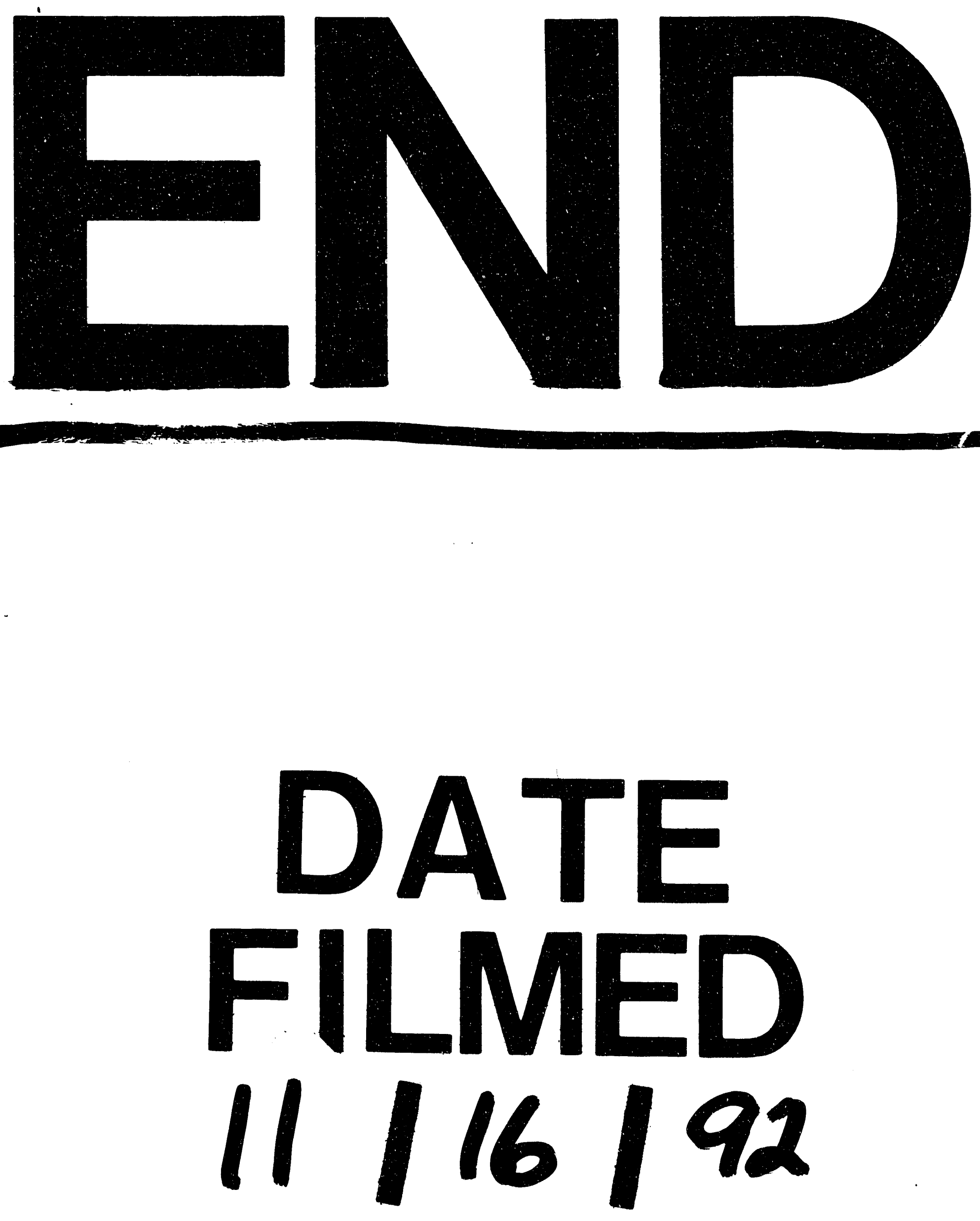


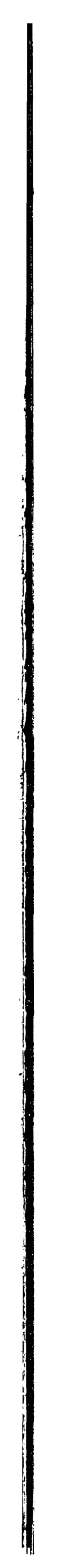

